This document is the accepted manuscript version of the following article:

Nedyalkova, L., Lothenbach, B., Renaudin, G., Mäder, U. \& Tits, J. (2019). Effect of redox conditions on the structure and solubility of sulfur- and selenium-AFm phases. Cement and Concrete Research, 123,

105803. https://doi.org/10.1016/j.cemconres.2019.105803

This manuscript version is made available under the CC-BY-NC-ND 4.0

license http://creativecommons.org/licenses/by-nc-nd/4.0/

\title{
1 Effect of redox conditions on the structure and solubility of sulfur- and seleni-
}

\section{2 um-AFm phases}

3 Latina Nedyalkova ${ }^{\mathrm{a}, \mathrm{b},{ }^{*}}$, Barbara Lothenbach $^{\mathrm{a}}$, Guillaume Renaudin ${ }^{\mathrm{c}}$, Urs Mäder $^{\mathrm{d}}$, Jan Tits ${ }^{\mathrm{b}}$

$4 \quad$ a) Laboratory for Concrete and Construction Chemistry, Empa, Dübendorf, Switzerland

5 b) Laboratory for Waste Management, Paul Scherrer Institute, Villigen PSI, Switzerland

$\left.6{ }^{c}\right)$ Université Clermont Auvergne, CNRS, SIGMA Clermont, ICCF, F-63000 Clermont-Ferrand, France

$7 \quad{ }^{d)}$ Institute of Geological Sciences, University of Bern, Switzerland

$8 \quad *$ Corresponding author.

$9 \quad$ E-mail address: latina.nedyalkova@empa.ch; latina_nedyalkova@abv.bg (L. Nedyalkova)

Keywords: AFm phase, solubility (B), waste management (E), selenium, sulfur

\section{Abstract}

In the context of safe radioactive waste disposal, the incorporation of selenium and sulfur, a major competitor for $\mathrm{Se}$, in AFm phases was investigated by synthesizing and characterizing $\mathrm{Se}(\mathrm{VI})-$, $\mathrm{Se}(\mathrm{IV})-$, S(VI)-, S(IV)-, S(II)-AFm phases to account for a range of possible redox conditions in a cement-based repository for low and intermediate level radioactive waste.

The X-ray spectra revealed crystalline AFm phases with trigonal or pseudo-trigonal structure. Different interlayer distances ( $\mathrm{hkl}$ 00l) were observed for the phases described in the hexagonal lattice, whereas no shift of the (hkl 110) diffraction peak was detected. The type of the interlayer anion seems to control the crystal symmetry of the AFm phase. The amount of water in the interlayer depends on the interlayer anion, relative humidity and temperature of exposure. The AFm phases show similar solubility 
products suggesting that high sulfur concentration in the cement pore solution can decrease Se binding by AFm phases.

\section{Introduction}

In blast furnace slag cements [1] and Portland cements blended with slags [2], $\mathrm{Fe}(0)$ and the reduced sulfur species, $\mathrm{HS}^{-}\left(\mathrm{S}^{-\mathrm{II}}\right.$, sulfide), from the slag lead to reducing conditions in the pore solution. Experimental investigations of the pore solution of such cements have shown that not only $\mathrm{HS}^{-}$from the slag reaction and $\mathrm{SO}_{4}{ }^{2-}\left(\mathrm{S}^{\mathrm{VI}}\right.$, sulfate) from Portland cement are present in the pore solution, but also the intermediate $\mathrm{SO}_{3}{ }^{2-}\left(\mathrm{S}^{\mathrm{IV}}\right.$, sulfite) and $\mathrm{S}_{2} \mathrm{O}_{3}{ }^{2-}\left(\mathrm{S}^{\mathrm{II}}\right.$, thiosulfate). The latter two originate from the partial oxidation of $\mathrm{HS}^{-}$and have been observed to persist for years in the pore solution of slag containing cements $[1,2]$. The binding of $\mathrm{SO}_{4}{ }^{2-}$ in $\mathrm{AFm}\left(\mathrm{Al}_{2} \mathrm{O}_{3}-\mathrm{Fe}_{2} \mathrm{O}_{3}\right.$-mono) and $\mathrm{AFt}\left(\mathrm{Al}_{2} \mathrm{O}_{3}-\mathrm{Fe}_{2} \mathrm{O}_{3}\right.$-tri) phases is well investigated (e.g. [3]), while much less is known whether and to which extend reduced sulfur species $\left(\mathrm{S}_{2} \mathrm{O}_{3}{ }^{2-}\right.$, $\mathrm{SO}_{3}{ }^{2-}$ and $\mathrm{HS}^{-}$) can be bound in AFm or AFt phases.

Reducing conditions are not only found in the presence of blast furnace slags, but also in the nearfield of deep geological repositories as foreseen in Switzerland for the disposal of low- and intermediate level nuclear waste (L/ILW), where cementitious materials will be a component of the waste matrix and will be used for the construction of the engineered barrier system [4]. Thermodynamic calculations predict an alkaline environment $(10<\mathrm{pH}<13.5)$ for the near field of such cement-based repositories and redox conditions evolving from an initial oxidising stage due to the residual oxygen entrapped in pore spaces, to anoxic conditions caused by the oxygen consumption by microorganisms, abiotic oxidation processes and the production of hydrogen by radiolysis. In the long term, the redox potential will range between $-750 \mathrm{mV}$ and $-230 \mathrm{mV}$ (SHE) assuming that redox conditions are mainly controlled by $\mathrm{Fe}(\mathrm{III}) / \mathrm{Fe}(\mathrm{II})$ mineral equilibria [5].

One of the dose-determining radionuclides potentially emanating from L/ILW repositories is considered to be selenium-79 due to its long half-life $\left(t_{1 / 2} \sim 3.27 \times 10^{5}\right.$ a) and expected weak retention by 
many common near- and far-field minerals as a result of its anionic speciation [4]. During the evolution of the redox conditions in the repository, several oxidation states of Se may occur and its aqueous speciation will be dominated by $\mathrm{SeO}_{4}{ }^{2-}\left(\mathrm{Se}^{\mathrm{VI}}\right.$, selenate) and $\mathrm{SeO}_{3}{ }^{2-}\left(\mathrm{Se}^{\mathrm{IV}}\right.$, selenite ion) under oxidizing conditions; $\mathrm{HSe}^{-}\left(\mathrm{Se}^{-\mathrm{II}}\right.$, selenide) and a series of polyselenides $\left(\mathrm{Se}_{x}{ }^{2-}, \mathrm{x}=2,3,4\right)$ under reducing conditions [6] (Fig. 1a). Depending on the composition of the cementitious matrix and the redox conditions, different anionic sulfur species, namely $\mathrm{SO}_{4}{ }^{2-}\left(\mathrm{S}^{\mathrm{VI}}\right.$, sulfate), $\mathrm{SO}_{3}{ }^{2-}\left(\mathrm{S}^{\mathrm{IV}}\right.$, sulfite $), \mathrm{S}_{2} \mathrm{O}_{3}{ }^{2-}$ ( $\mathrm{S}^{\mathrm{II}}$, thiosulfate) and $\mathrm{HS}^{-}\left(\mathrm{S}^{-\mathrm{II}}\right.$, sulfide), may also be present. The sulfur anions are isostructural with the selenium ones and have similar chemical properties. Thus, a strong influence of sulfur on the selenium binding is expected. $\mathrm{SO}_{3}{ }^{2-}$ and $\mathrm{S}_{2} \mathrm{O}_{3}{ }^{2-}$ are thermodynamically metastable relative to the main species $\mathrm{SO}_{4}{ }^{2-}$ and $\mathrm{HS}^{-}$ (Fig. $\mathrm{Ib}$ and $1 \mathrm{c}$ ). Reduced sulfur species $\left(\mathrm{HS}^{-}, \mathrm{SO}_{3}{ }^{2-}\right.$ and $\mathrm{S}_{2} \mathrm{O}_{3}{ }^{2-}$ ), however, are observed to persist in pore solutions of blast furnace slag cement due to slow oxidation kinetics $[1,7]$.

A potential retardation mechanism for the hazardous Se anions is their uptake by positively charged anion exchangers, such as AFm phases, present in the cementitious near-field. AFm $\left(\mathrm{Al}_{2} \mathrm{O}_{3}-\mathrm{Fe}_{2} \mathrm{O}_{3}-\right.$ mono) phases are calcium aluminate-ferrite hydrates belonging to the layered double hydroxide (LDH) family. They are formed during the hydration of cement and have the general formula $\left[\mathrm{Ca}_{4}(\mathrm{Al}, \mathrm{Fe})_{2}(\mathrm{OH})_{12}\right] \cdot \mathrm{X} \cdot \mathrm{nH}_{2} \mathrm{O}$ where $\mathrm{X}$ stands for either two monovalent anions or a bivalent anion. The structure is composed of positively charged main layers, $\left[\mathrm{Ca}_{4}(\mathrm{Al}, \mathrm{Fe})_{2}(\mathrm{OH})_{12}\right]^{2+}$, and negatively charged interlayers, $\left[\mathrm{X} \cdot \mathrm{nH}_{2} \mathrm{O}\right]^{2-}$, with $\mathrm{n}$ giving the number of interlayer water molecules. The amount of water in the interlayer varies depending on the type of interlayer anion, the temperature and the relative humidity [8]. Although the most common interlayer anions found in the $\mathrm{AFm}$ are $\mathrm{OH}^{-}, \mathrm{SO}_{4}{ }^{2-}, \mathrm{Cl}^{-}$and $\mathrm{CO}_{3}{ }^{2-}$ $[3,9]$, a variety of other anions can be incorporated as well in the AFm structure, such as $\mathrm{NO}_{3}{ }^{-}[10], \mathrm{I}^{-}$ [11], $\mathrm{Br}^{-}[12], \mathrm{CrO}_{4}{ }^{2-}[13,14]$, or $\mathrm{MoO}_{4}{ }^{2-}[15]$. Bi-anionic AFm phases, containing more than one type of interlayer anion, may also form and have been reported in literature $[11,16-20]$. Thus AFm phases may provide a large potential for the immobilization of the Se anions due to these interlayer anion exchange sites. 
The ability of the AFm phases to bind Se has already been studied before, but a more comprehensive understanding of the sorption mechanism as well as of the effect of the competition with $\mathrm{S}$ is still needed. Several studies so far have focused on the formation of Se-AFm and S-AFm phases. Se(VI)-, Se(IV)- and Se(-II)-AFm have been synthesized (e.g. [21-24]) but their crystal structure has not yet been resolved. The formation of the $\mathrm{S}(\mathrm{VI})$-AFm (monosulfate), on the other hand, has been extensively studied and its structure refined in the rhombohedral $R \overline{3}$ space group [25]. Monosulfate is known to exist in several hydration states - Ms9, Ms10.5, Ms12 and Ms14 (with the index number giving the water content of the phase per unit cell in moles), in dependence of the exposure temperature and relative humidity. As the water molecules are incorporated in the interlayer, each hydrate has a specific interlayer distance [26, 27]. The S(IV)-AFm [28] and the S(-II)-AFm [29] phases have been synthesized and their crystal structure characterized revealing a rhombohedral structure for both phases, but no solubility measurements have been performed. The existence of a S(II)-AFm phase has been suggested previously [30], however, it has not yet been synthesized.

This study aims to extend the current knowledge on the incorporation of Se and S in AFm phases by gaining a better insight into the crystal structure, hydration states and solubility of the various Se-AFm and S-AFm phases and also to consider the effect of competition between these chemically similar elements for the available AFm sites. Se(VI)-, Se(IV)-, S(VI)-, S(IV)-, S(II)-AFm phases were synthesized and investigated with the aim of accounting for a range of possible redox conditions in a cementbased repository. Due to the difficulties related to the stabilization of the strongly reduced Se(-II) and S(-II) anionic species and the different techniques required for their synthesis and characterization, AFm phases containing these anions were not included. 

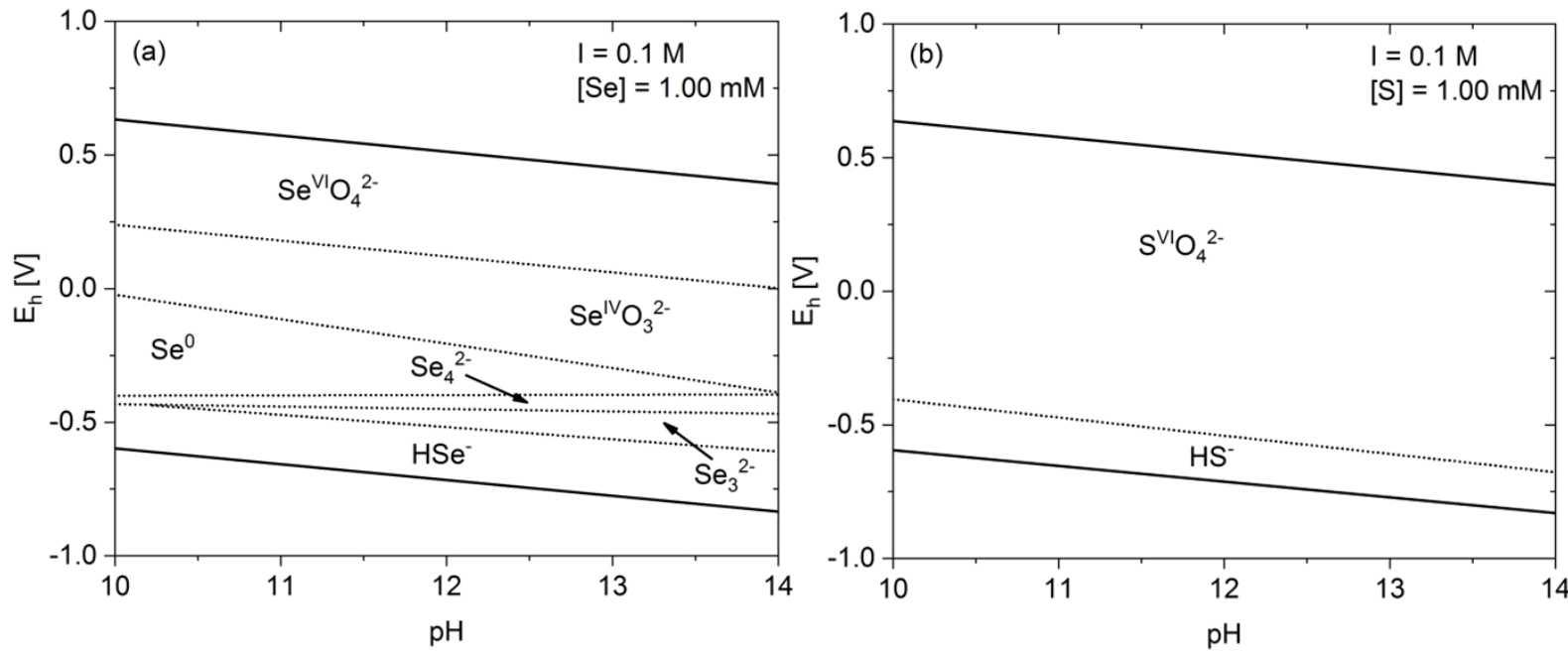

100

101

102

103

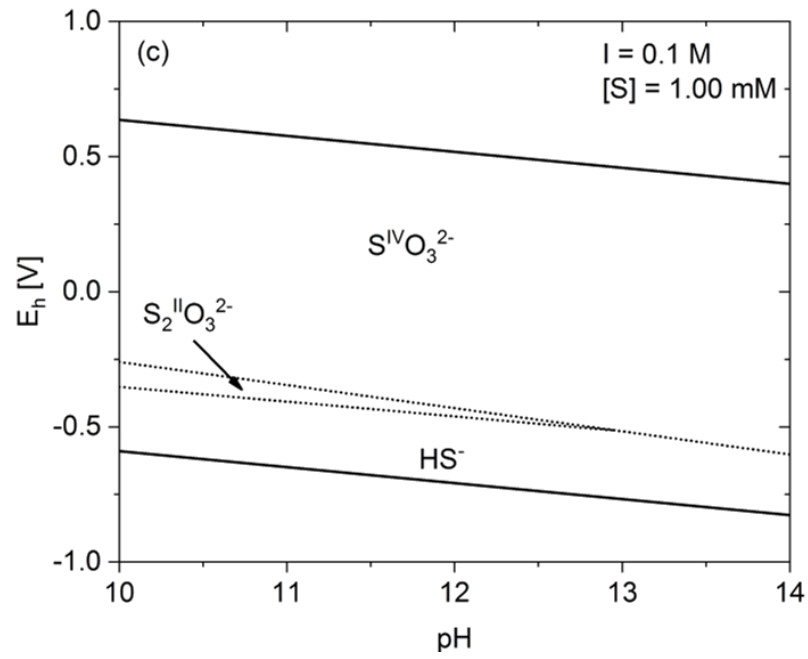

107

Figure 1: Predominance diagrams for selenium (a) and sulfur (b); Eh-pH diagram for the metastable sulfur species $\mathrm{SO}_{3}{ }^{2-}$ and $\mathrm{S}_{2} \mathrm{O}_{3}{ }^{2-}$ (c). Calculations were performed using the Medusa code [31] and thermodynamic data from the NEA thermodynamic database [32].

\section{Materials and Methods}

\subsection{Synthesis of AFm phases}

All sample manipulations were performed in a $\mathrm{N}_{2}$-filled glove box to minimize atmospheric $\mathrm{CO}_{2}$ contamination. Solutions were prepared using high-purity deionized water (resistivity $=18.2 \mathrm{M} \Omega \mathrm{cm}$ ) generated by a Milli-Q Gradient A10 System (Millipore, Bedford, USA). All chemicals were analytical grade reagents. The following chemicals were used: $\mathrm{CaO}, \mathrm{CaCO}_{3}, \mathrm{Al}_{2} \mathrm{O}_{3}, \mathrm{Na}_{2} \mathrm{SO}_{4}, \mathrm{Na}_{2} \mathrm{SO}_{3}, \mathrm{Na}_{2} \mathrm{~S}_{2} \mathrm{O}_{3} \cdot 5 \mathrm{H}_{2} \mathrm{O}$, 
Elements, Los Angeles, California, USA). Tricalcium aluminate $\left(C_{3} A\right)$ was prepared by mixing appropri-

ate amounts of $\mathrm{CaCO}_{3}$ with $\mathrm{Al}_{2} \mathrm{O}_{3}$ powder to achieve a molar ratio of $3: 1$ and by heating the mixture at $800^{\circ} \mathrm{C}$ for $1 \mathrm{~h}$, at $1000^{\circ} \mathrm{C}$ for another $4 \mathrm{~h}$ and finally at $1425^{\circ} \mathrm{C}$ for $24 \mathrm{~h}$. The clinkers were then ground to $<63 \mu \mathrm{m}$. The powder was checked by X-ray diffraction to confirm the formation of cubic $C_{3} A$ (PDF: 00038-1429). To ensure that no $\mathrm{CO}_{2}$ contamination of $\mathrm{CaO}$ occurred, the latter compound was heated at $900^{\circ} \mathrm{C}$ for $12 \mathrm{~h}$ prior to the start of the synthesis. All Na- and Ca-salts were tested for the presence of absorbed $\mathrm{H}_{2} \mathrm{O}$ by thermogravimetric analysis (TGA) to determine their actual composition.

The AFm phases were synthesized by mixing approximately $2 \mathrm{~g}$ of the starting materials $\mathrm{C}_{3} \mathrm{~A}, \mathrm{CaO}$, and the appropriate $\mathrm{Na}_{2}-\mathrm{X}$ salt in stoichiometric amounts (in 1:1:1 molar ratio) in $50 \mathrm{ml}$ of ultrapure water resulting in a $\mathrm{Na}$ concentration of $0.2 \mathrm{M}$ and $\mathrm{pH}$ of $\sim 13$. The $\mathrm{S}(\mathrm{VI})-\mathrm{AFm}$ and $\mathrm{Se}(\mathrm{IV})-\mathrm{AFm}$ phases were also prepared at $\mathrm{pH} 12$ using $\mathrm{Ca}-\mathrm{X}$ salts. For the $\mathrm{S}(\mathrm{IV})-$, $\mathrm{S}(\mathrm{II})-$ and $\mathrm{Se}(\mathrm{VI})-\mathrm{AFm}$ no Ca-X salts were commercially available.

The samples were equilibrated for three or six months, in closed PE-bottles at $20^{\circ} \mathrm{C}$ on end-over-end shakers (100 rpm). After equilibration, the solid and liquid phases were separated by vacuum filtration through a $0.45 \mu \mathrm{m}$ nylon filter. The solid phases were dried in a desiccator over a saturated $\mathrm{NaOH}$ solution ( $~ 8 \%$ relative humidity) at room temperature for five to six weeks under vacuum.

\subsection{Characterization of the solid phases}

After drying, the samples were analysed by X-ray powder diffraction (XRPD), thermogravimetric analysis (TGA), infrared (FTIR) and Raman spectroscopy, and dynamic vapour sorption (DVS).

XRPD analyses were performed on a PANalytical X'Pert Pro MPD diffractometer using CuK $\alpha$ radiation $(\lambda=1.54184 \AA)$; the diffraction patterns were recorded between $5<2 \theta<70^{\circ}$ with a step size of $0.017^{\circ}$ (20) and a counting time of $0.6 \mathrm{~s}$ per step. For the Rietveld refinement, XRPD patterns were recorded on a PANalytical X'Pert Pro diffractometer with $\theta-\theta$ geometry, equipped with a solid X-Celerator detec- 
tor and using CuK $\alpha$ radiation. XRPD patterns were recorded at room temperature in the interval $3^{\circ}<$ $2 \theta<120^{\circ}$, with a step size of $0.0167^{\circ}$ and a counting time of $2 \mathrm{~s}$ for each data value. A total counting time of about 200 min was used for each sample. An attempt to solve the crystal structures of the AFm phases was done using X-Cell software to determine the unit cell symmetry [33], FOX software to locate the unit cell objects [34] and, finally, structure refinement was done by the Rietveld method with the FULLPROF software [35].

TGA was carried out on a TGA/SDTA 851 instrument (Mettler Toledo, Switzerland). The samples ( 15 $\mathrm{mg}$ ) were heated under a $\mathrm{N}_{2}$ atmosphere over the temperature range between 30 and $980^{\circ} \mathrm{C}$ at a heating rate of $20^{\circ} \mathrm{C} / \mathrm{min}$. The obtained mass losses were then used to determine the water content of the solids. In order to characterize the different functional groups and the type of structurally bound water $\left(\mathrm{OH}\right.$ or $\left.\mathrm{H}_{2} \mathrm{O}\right)$ of the AFm phases, attenuated total reflectance infrared spectra were recorded in the 4000 to $600 \mathrm{~cm}^{-1}$ range on a Bruker Tensor 27 FTIR spectrometer. Raman spectroscopy measurements were carried out on a Raman Bruker Senterra instrument using a $532 \mathrm{~nm}$ laser and a $3.5 \mathrm{~cm}^{-1}$ spectral resolution to determine the vibrational characteristics of the molecules in the structure.

The water sorption kinetics of the samples were studied with a VTI-SA Dynamic Vapour Sorption (DVS) apparatus (TA Inc, USA). The relative humidity (RH) was varied between $5,10,20,30,50,60,70,80,85$, $90,92,94,90,80,70,50,30,20,10$, and $5 \%$ at $25^{\circ} \mathrm{C}$ with a data logging interval of $1 \mathrm{~min}$. The equilibrium criterion for each $\mathrm{RH}$ step was set to $0.0065 \mathrm{wt}$. \% of the sample mass in $5 \mathrm{~min}$ for a maximum equilibration time of 720 min; equilibrium was reached for all samples within the maximum equilibration time. The reference mass was obtained by drying the sample at $105^{\circ} \mathrm{C}$ and $0 \% \mathrm{RH}$. 
1713000 ion chromatography system equipped with a Dionex Ion Pac AS25 column for $\mathrm{SO}_{4}, \mathrm{SO}_{3}, \mathrm{~S}_{2} \mathrm{O}_{3}$,

$172 \mathrm{SeO}_{4}$ and $\mathrm{SeO}_{3} ;$ a Dionex Ion Pac CS12A column for $\mathrm{Na}$ and $\mathrm{Ca}$; and a Dionex Ion Pac CS5A column for

173 Al. The eluents used were $37 \mathrm{ml}$ of $1.0 \mathrm{M} \mathrm{NaOH} / 1$ I water for the anions, $1.3 \mathrm{ml}$ of $\geq 99.5 \%$ methanesul-

174 fonic acid (MSA)/1 I water for $\mathrm{Na}$ and $\mathrm{Ca}$, and $74 \mathrm{ml}$ of $32 \% \mathrm{HCl} / 1$ I water for $\mathrm{Al}$, respectively. The dis-

175 solved $\mathrm{Al}$ and $\mathrm{S}_{2} \mathrm{O}_{3}$ concentrations were quantified in the undiluted solutions; for the other elements

176 the samples were diluted by a factor of $1: 10$ in the case of $\mathrm{SO}_{4}, \mathrm{SO}_{3}, \mathrm{SeO}_{4}$ and $\mathrm{SeO}_{3}$; and 1:100 in the 177 case of $\mathrm{Na}$ (and $\mathrm{Ca}$ in the case of the $\mathrm{pH} 12$ samples).

178

\subsection{Experimental and analytical challenges}

Sulfite oxidation: In dilute alkaline solutions, it was observed that sulfite was unstable outside of the $\mathrm{N}_{2}$-filled glovebox and tended to oxidize slowly to sulfate. To stabilize sulfite for the IC measurements, the IC standards and sample dilutions were prepared in the glovebox where $100 \mu$ of formaldehyde solution (in a 1:1000 dilution) were added to $10 \mathrm{ml}$ aliquot of each standard and sample. A small portion of the sulfite in solution, however, still oxidized and the IC results had to be corrected. The data were corrected by subtracting the $\mathrm{SO}_{4}$ concentration from the total $\mathrm{S}$ concentration of the IC standards and attributing the remaining portion to $\mathrm{SO}_{3}$. The $\mathrm{SO}_{3}$ concentration obtained in this manner was then plotted against the measured $\mathrm{SO}_{3}$ peak area resulting in a linear relationship used to correct all further measurements. For some samples, the quality of the correction was controlled by ICP-OES measurements. In the thiosulfate samples no oxidation was observed.

\subsection{Calculation of thermodynamic data}

The measured concentrations of calcium, sodium, aluminium, sulfur and selenium in the liquid phase in equilibrium with the solids were used to calculate the solubility products of the synthesized AFm phases by using the thermodynamic modelling program GEMS [36] and the NAGRA/PSI database [37], in- 
cluding a full speciation calculation. The activity coefficients of the aqueous species were calculated with the built-in extended Debye-Hückel equation and $\mathrm{NaOH}$ as a background electrolyte. The solubility products refer to $\mathrm{Ca}^{2+}, \mathrm{AlO}_{2}{ }^{-}, \mathrm{OH}^{-}, \mathrm{H}_{2} \mathrm{O}, \mathrm{SO}_{4}{ }^{2-}, \mathrm{SO}_{3}{ }^{2-}, \mathrm{S}_{2} \mathrm{O}_{3}{ }^{2-}, \mathrm{SeO}_{4}{ }^{2-}$ and $\mathrm{SeO}_{3}{ }^{2-}$, respectively and solids with $4 \mathrm{Ca}$ within the main layer (eg. $\mathrm{K}_{\mathrm{s}}(\mathrm{S}(\mathrm{VI})-\mathrm{AFm})=\left\{\mathrm{Ca}^{2+}\right\}^{4}\left\{\mathrm{AlO}_{2}\right\}^{2}\left\{\mathrm{SO}_{4}{ }^{2-}\right\}\left\{\mathrm{OH}^{-}\right\}^{4}\left\{\mathrm{H}_{2} \mathrm{O}\right\}^{12}$ for Ms14). From the calculated solubility products also the Gibbs free energy of formation for each phase was calculated. The entropy $S$ and the heat capacity $C_{p}^{0}$ of monosulfate with different hydration states has been determined experimentally [27] while for $3 \mathrm{CaO} \cdot \mathrm{Al}_{2} \mathrm{O}_{3} \cdot \mathrm{CaSO}_{3} \cdot 11 \mathrm{H}_{2} \mathrm{O}$, $3 \mathrm{CaO} \cdot \mathrm{Al}_{2} \mathrm{O}_{3} \cdot \mathrm{CaS}_{2} \mathrm{O}_{3} \cdot 13 \mathrm{H}_{2} \mathrm{O}, 3 \mathrm{CaO} \cdot \mathrm{Al}_{2} \mathrm{O}_{3} \cdot \mathrm{CaSeO}_{4} \cdot 13 \mathrm{H}_{2} \mathrm{O}$ and $3 \mathrm{CaO} \cdot \mathrm{Al}_{2} \mathrm{O}_{3} \cdot \mathrm{CaSeO}_{3} \cdot 11 \mathrm{H}_{2} \mathrm{O}$ no measured data are available. The entropy and heat capacities values were thus estimated based on the following reference reactions using $3 \mathrm{CaO} \cdot \mathrm{Al}_{2} \mathrm{O}_{3} \cdot \mathrm{CaSO}_{4} \cdot 12 \mathrm{H}_{2} \mathrm{O}[27]$ :

$3 \mathrm{CaO} \cdot \mathrm{Al}_{2} \mathrm{O}_{3} \cdot \mathrm{CaSO}_{3} \cdot 11 \mathrm{H}_{2} \mathrm{O} \Leftrightarrow 3 \mathrm{CaO} \cdot \mathrm{Al}_{2} \mathrm{O}_{3} \cdot \mathrm{CaSO}_{4} \cdot 12 \mathrm{H}_{2} \mathrm{O}-\mathrm{H}_{2} \mathrm{O}-\mathrm{SO}_{4}{ }^{2-}+\mathrm{SO}_{3}{ }^{2-}$

$3 \mathrm{CaO} \cdot \mathrm{Al}_{2} \mathrm{O}_{3} \cdot \mathrm{CaS}_{2} \mathrm{O}_{3} \cdot 13 \mathrm{H}_{2} \mathrm{O} \Leftrightarrow 3 \mathrm{CaO} \cdot \mathrm{Al}_{2} \mathrm{O}_{3} \cdot \mathrm{CaSO}_{4} \cdot 12 \mathrm{H}_{2} \mathrm{O}+\mathrm{H}_{2} \mathrm{O}-\mathrm{SO}_{4}{ }^{2-}+\mathrm{S}_{2} \mathrm{O}_{3}{ }^{2-}$

$3 \mathrm{CaO} \cdot \mathrm{Al}_{2} \mathrm{O}_{3} \cdot \mathrm{CaSeO}_{4} \cdot 13 \mathrm{H}_{2} \mathrm{O} \Leftrightarrow 3 \mathrm{CaO} \cdot \mathrm{Al}_{2} \mathrm{O}_{3} \cdot \mathrm{CaSO}_{4} \cdot 12 \mathrm{H}_{2} \mathrm{O}+\mathrm{H}_{2} \mathrm{O}-\mathrm{SO}_{4}{ }^{2-}+\mathrm{SeO}_{4}{ }^{2-}$

$3 \mathrm{CaO} \cdot \mathrm{Al}_{2} \mathrm{O}_{3} \cdot \mathrm{CaSeO}_{3} \cdot 11 \mathrm{H}_{2} \mathrm{O} \Leftrightarrow 3 \mathrm{CaO} \cdot \mathrm{Al}_{2} \mathrm{O}_{3} \cdot \mathrm{CaSO}_{4} \cdot 12 \mathrm{H}_{2} \mathrm{O}-\mathrm{H}_{2} \mathrm{O}-\mathrm{SO}_{4}{ }^{2-}+\mathrm{SeO}_{3}{ }^{2-}$

Selecting an isocoulombic reaction as the model reaction, in which the exchange of anions of same charge takes place, allowed to assume that the $\Delta C_{p}$ and $\Delta S$ terms are close to zero [38]. The entropy and heat capacity of $\mathrm{SO}_{4}{ }^{2-}, \mathrm{SO}_{3}{ }^{2-}, \mathrm{S}_{2} \mathrm{O}_{3}{ }^{2-}, \mathrm{SeO}_{4}{ }^{2-}, \mathrm{SeO}_{3}{ }^{2-}$, and $\mathrm{H}_{2} \mathrm{O}$ were taken from the GEMS Nagra/PSI thermodynamic database [37].

\section{Results and discussion}

\subsection{X-ray diffraction patterns}

The synthesized phases were characterized by XRPD. Crystal structure solution and refinement were attempted for the S(IV)-, S(II)-, Se(VI)- and Se(IV)-AFm samples. The structure of the S(VI)-AFm phase was refined by Allmann [25] and the phase is used as a reference. The XRD analyses revealed well- 
crystalline AFm phases showing high-intensity basal reflexions (hkl 00l) at low $2 \theta$ values and the (110) diffraction peak of the basal plane at $\sim 31^{\circ} 2 \theta$ characteristic for the AFm family.

Ms14 is the stable hydration state at $100 \% \mathrm{RH}$ and temperatures above $18^{\circ} \mathrm{C}$, and it dehydrates to 


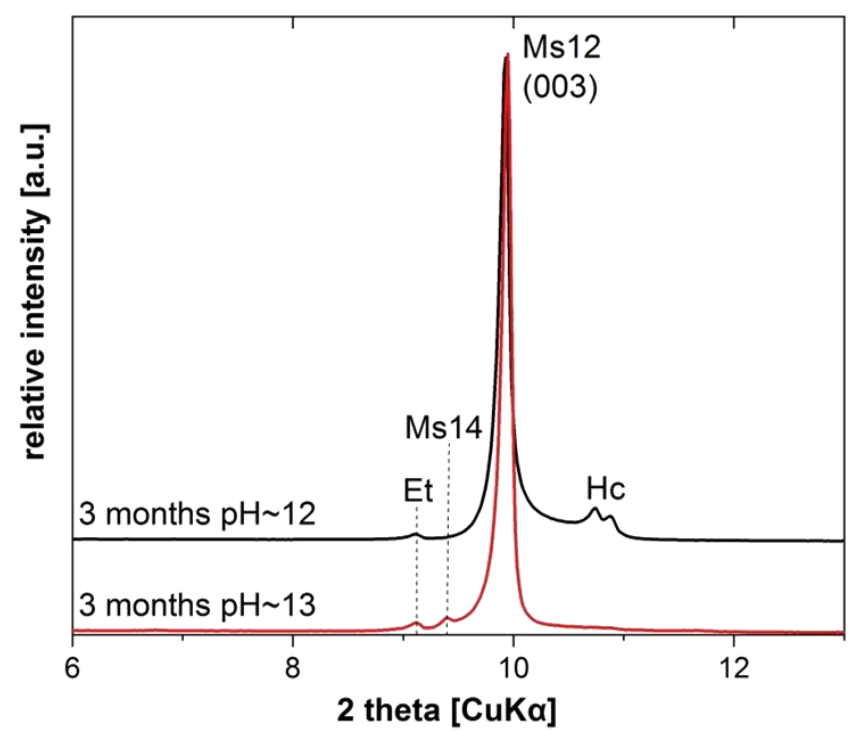
with $12 \mathrm{H}_{2} \mathrm{O}$ molecules, Ms14: monosulfate with $14 \mathrm{H}_{2} \mathrm{O}$ molecules. AFm phase containing only minor impurities of portlandite $\left(\mathrm{Ca}(\mathrm{OH})_{2}\right)$ (Fig. 3). The first diffraction peak at $\sim 10.4^{\circ} 2 \theta$ has a right shoulder indicating most probably the presence of small amounts of a less hydrated AFm phase or a lowering of symmetry. Nevertheless, for the crystal structure refinement data have been treated by considering a single AFm phase sample with hexagonal unit cell, thus omitting the shoulder and its harmonics. The portlandite impurities, however, were taken into account for the refinement. group. The refined lattice parameters are $a=5.7693(6) \AA$ and $c=25.533(3) \AA$ indicating an interlayer distance of $8.51 \AA$. The intercalated anion respects the geometrical feature of pyramidal sulfite with a S-O distance of $1.51 \AA$ and a O-S-O angle of $106^{\circ}$. Two distinct structure solutions can be found with either the sulfite $\mathrm{SO}_{3}{ }^{2-}$ anion normal to the main layer and connected to calcium cation, or parallel to 
the main layer at the center of the interlayer region. These two different configurations result in similar Rietveld agreement factors, due to the difficulty to correctly model the diffraction peak shape. Nevertheless, the comparison with previously determined equivalent crystal structure from single data allow us to favour the parallel orientation. The crystal structure of the $\mathrm{NO}_{3}-\mathrm{AFm}$ phase is characterized by planar trigonal $\mathrm{NO}_{3}{ }^{-}$anion perpendicular to the main layer (bonded to $\mathrm{Ca}^{2+}$ ) resulting in a larger interlayer distance of $8.62 \AA$ (even though the $\mathrm{N}-\mathrm{O}$ bond distance of $1.22 \AA$ is shorter than the S-O distance of about $1.51 \AA$ ) [10]. Then the smaller interlayer distance of the S(IV)-AFm suggests a sulfite orientation parallel to the main layer. The comparison with the $\mathrm{HBO}_{3}-\mathrm{AFm}$, in which the planar triangular anion is parallel to the main layer in the center of the interlayer region resulting in an interlayer distance of $8.26 \AA[40]$, also supports the idea of the parallel central interlayer position. Complementary observations, namely by the preparation of single crystals, are needed to definitively confirm this orientation. The structural parameters assuming a parallel central interlayer position described in the rhombohedral $R \overline{3}$ space group are summarized in Table 1 , and Figure 3 shows the corresponding Rietveld plot. The refined composition corresponds to $\left[\mathrm{Ca}_{2} \mathrm{Al}(\mathrm{OH})_{6}\right] \cdot\left[1 / 2 \mathrm{SO}_{3} \cdot 2 \cdot 1 \mathrm{H}_{2} \mathrm{O}\right]$, or $3 \mathrm{CaO} \cdot \mathrm{Al}_{2} \mathrm{O}_{3} \cdot \mathrm{CaSO}_{3} \cdot 10.2 \mathrm{H}_{2} \mathrm{O}$, slightly below the obtained 11 water molecules per formula unit determined by the chemical analysis (see chapter 3.2.1).

Motzet \& Pöllmann [28] assigned the S(IV)-AFm unit cell to the trigonal space groups $P 3$ or $P \overline{3}$ with the refined lattice parameters $a=5.7709(4) \AA$ and $c=51.284(5) \AA$ (twice the unit cell used here). 

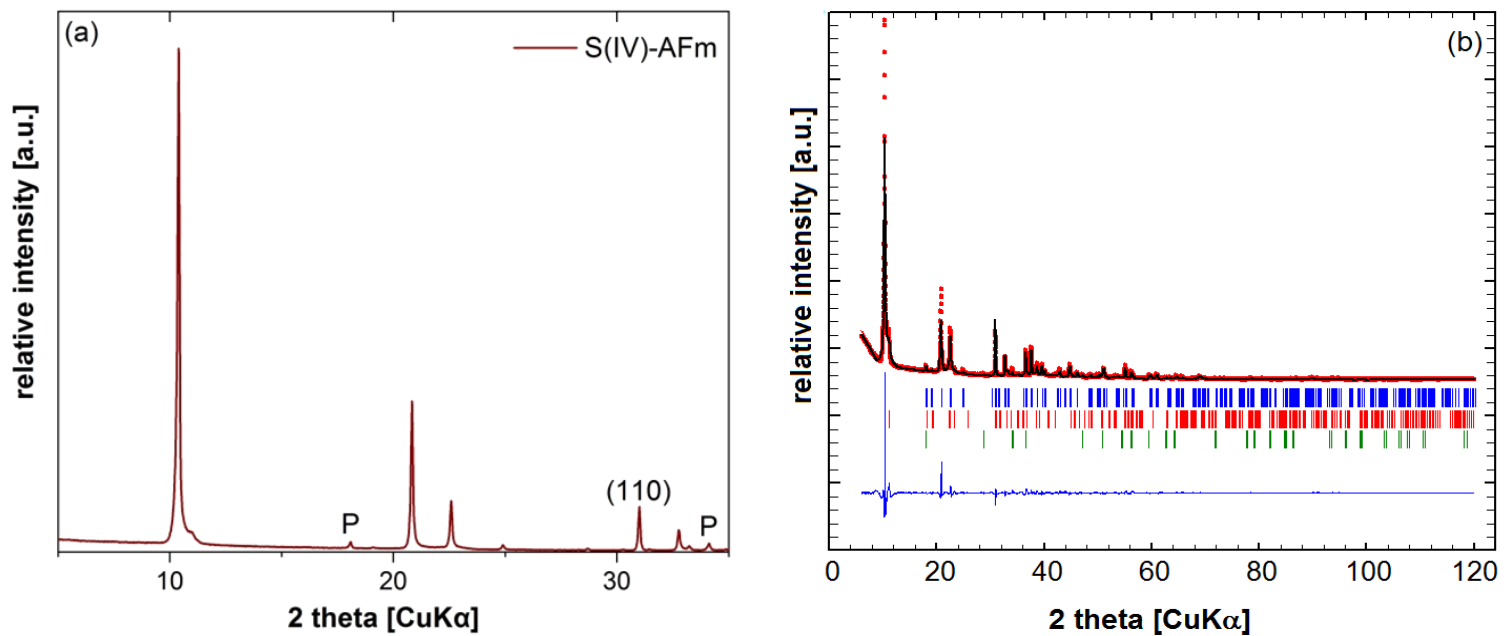

(c)

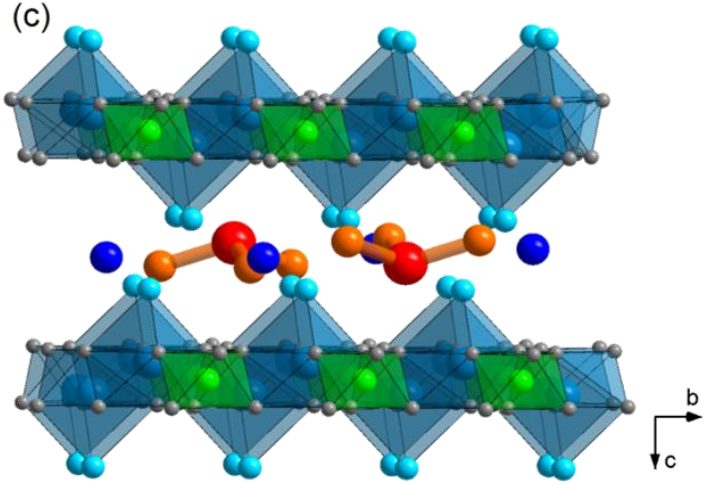

Figure 3: (a) XRPD pattern and (b) Rietveld plot of the S(IV)-AFm sample ( $\mathrm{pH}$ 13) showing the diffraction experimental pattern (red dots), the calculated pattern (black line), the difference curve (blue line) and sticks for Bragg peaks positions for the resolved S(IV)-AFm phase (blue), for the unresolved underhydrate $3 \mathrm{CaO} \cdot \mathrm{Al}_{2} \mathrm{O}_{3} \cdot \mathrm{CaSO}_{3} \cdot \mathrm{XH}_{2} \mathrm{O}$ (red) and for portlandite impurity (green). P: portlandite. (c) General representation of the structural model for the S(IV)-AFm phase, projection almost along [100]. The $\mathrm{SO}_{3}{ }^{2-}$ anion is shown in red and orange, the Ca polyhedra in light blue, Al octahedra in green, hydroxyl in grey, bonded water from the main layer in light blue and interlayer water molecules in dark blue. For clarity reasons, the disordered interlayer part of the structure is presented in an ordered way. 
Table 1: Rietveld refinement of the S(IV)-AFm phase. Standard deviations ( $\sigma$ values from Rietveld treatments) are indicated in parentheses.

\begin{tabular}{|c|c|c|c|c|c|c|}
\hline Atom & Site & $x$ & $y$ & $z$ & $B_{\text {iso }}$ & Occupancy \\
\hline \multicolumn{7}{|c|}{$R \overline{3}, \mathrm{Z}=3$} \\
\hline \multicolumn{7}{|c|}{$a=5.7693(6) \AA, c=25.533(1) \AA, V=736.0(1) \AA^{3}$} \\
\hline \multicolumn{7}{|c|}{$R_{\text {Bragg }}=0.034, R_{\mathrm{p}}=0.14, R_{\mathrm{wp}}=0.16$} \\
\hline Al & $3 a$ & 0 & 0 & 0 & $1.0(-)$ & $1(-)$ \\
\hline $\mathrm{Ca}$ & $6 c$ & $2 / 3$ & $1 / 3$ & $0.0220(3)$ & $1.0(-)$ & $1(-)$ \\
\hline $\mathrm{O} 1\left(\mathrm{OH}^{-}\right)$ & $18 f$ & $0.253(3)$ & $0.940(3)$ & $0.0370(9)$ & $1.0(-)$ & $1(-)$ \\
\hline $\mathrm{O} 2\left(\mathrm{H}_{2} \mathrm{O}\right)$ & $6 c$ & 0 & 0 & $0.7875(9)$ & $1.0(-)$ & $1(-)$ \\
\hline S & $6 c$ & 0 & 0 & $0.489(1)$ & $1.0(-)$ & $1 / 4(-)$ \\
\hline $\mathrm{O} 3\left(\mathrm{SO}_{3}\right)$ & $18 f$ & $0.08(1)$ & $0.269(6)$ & $0.513(2)$ & $1.0(-)$ & $1 / 4(-)$ \\
\hline $\mathrm{O} 4\left(\mathrm{H}_{2} \mathrm{O}\right)$ & $3 b$ & 0 & 0 & 0.5 & $1.0(-)$ & $0.06(2)$ \\
\hline
\end{tabular}
talline AFm phase. The crystallinity of the phase showed no clear dependence on the aging time, however, a pH dependence was observed: a Se(IV)-AFm formed at $\mathrm{pH} \sim 13$ has only weakly defined diffraction peaks, whereas at $\mathrm{pH} 12$ the diffraction peaks are more intense (Fig. 4). Therefore, the crystal structure analysis was only carried out for the AFm sample synthesized at $\mathrm{pH} 12$. The structure analysis was still limited due to the presence of two distinct AFm phases - i.e. two Se(IV)-AFm hydrates. These two hydrates seem to have a hexagonal unit cell with the refined interlayer distances $11.05 \AA$ and $9.65 \AA$, respectively.

Ma et al. [41] observed the formation of Se(IV)-AFm phases with two distinct interlayer distances in a series of sorption experiments of $\mathrm{SeO}_{3}{ }^{2-}$ onto $\mathrm{Cl}-\mathrm{AFm}$ and $\mathrm{SO}_{4}-\mathrm{AFm}$. $\mathrm{SeO}_{3}{ }^{2-}$ intercalation in the inter- 
layer resulted in the formation of Se(IV)-AFm phases with interlayer distances $11.01 \pm 0.01 \AA$ and $9.99 \pm 0.01 \AA$ in the case of the $\mathrm{Cl}-\mathrm{AFm}$, and $11.06 \pm 0.01 \AA$ and $9.87 \pm 0.01 \AA$ in the case of the $\mathrm{SO}_{4}-\mathrm{AFm}$. Based on EXAFS experiments, the authors attributed the two types of Se(IV)-AFm formed to different complexation configurations of the $\mathrm{SeO}_{3}{ }^{2-}$ anions in the interlayer: the phases with the larger spacing of $\sim 11.1 \AA$ contain free hydrated $\mathrm{SeO}_{3}{ }^{2-}$, whereas inner-sphere complexation of Se accounts for the smaller d-values of $\sim 9.9 \AA$. The two Se(IV)-AFm hydrates observed in this study show similar interlayer distances to the ones investigated earlier by Ma et al. [41] suggesting that the differences may arise from the different types of coordination environments of the intercalated $\mathrm{SeO}_{3}{ }^{2-}$ anions. While the 9.65 $\AA$ hydrate might contain $\mathrm{SeO}_{3}{ }^{2-}$ bonded to the main layer, the larger d-value of the $11.05 \AA$ hydrate could be explained with free Se(IV) in the interlayer.

The Se(IV)-AFm structural analysis has shown two distinct symmetries for the two hydrates: a rhombohedral symmetry with a hexagonal axis corresponding to three interlayers for the $11.05 \AA$ hydrate $(R \overline{3}$, $Z=3, a=5.7752(9) \AA, c=33.162(12) \AA)$ and a trigonal symmetry with a hexagonal axis corresponding to two interlayers for the $9.65 \AA$ hydrate $(P \overline{3}, Z=2, a=5.7752(9) \AA, c=19.300(9) \AA)$. A structure solution has been searched for the $9.65 \AA$ hydrate with the FOX software using two independent main layers, two independent water molecules and one selenite group. The $\mathrm{SeO}_{3}$ geometry has been fixed with Se-O distances of $1.69 \AA$, O-O distances of $2.64 \AA$ and $\mathrm{O}-\mathrm{Se}-\mathrm{O}$ angle of $103^{\circ}$ according to distances and angles averages from the $\mathrm{CaSeO}_{3}$ crystal structure [42]. Structural models proposed by FOX [34] invariably suggest selenite anion in front of calcium cations from one main layer out of two, explaining thus the periodicity based on two interlayers. Selenite anions are oriented almost perpendicularly to the layers with the four atoms (one selenium atom and three independent oxygen atoms) located on general positions with half of one third occupancies (to respect electro-neutrality). The best solution found is presented in Table 2. All the proposed structural models could not be refined with FullProf [35], most probably due to a non-hexagonal real symmetry (monoclinic or triclinic lowering of symmetry). The proposed structure for the Se(IV)-AFm is very similar to the one of the $\mathrm{NO}_{3}-\mathrm{AFm}[10]$, in which the anion is bonded to a calcium, is oriented perpendicularly to the main layer and shows disor- 
der around the trigonal (or pseudo-trigonal) axis. The selenite anion is connected to a calcium cation via a bidentate ionic bonding with two $\mathrm{Ca} 2-\mathrm{O} 5$ and $\mathrm{Ca} 2-\mathrm{O} 6$ distances of about $2.5 \AA$, similarly to the calcium environment in the $\mathrm{CaSeO}_{3}$ crystal structure [42]. It is interesting to note that this structural organization corresponds to the one found by Ma et al. [41] for their $9.87 \AA$ Se(IV)-AFm based on EXAFS measurements. The lack of better quality powder patterns (despite numerous attempts to synthesize a single phase sample with high crystallinity), or more simply the absence of single crystals, did not allow further structural resolution of the $9.65 \AA$ Se(IV)-AFm compound, nor was it possible to work on a structural model for the $11.05 \AA$ Se(IV)-AFm compound. 
Table 2: Best - unrefined - structure solution proposed by FOX software for the Se(IV)-AFm phase of

371 composition $\left[\mathrm{Ca}_{2} \mathrm{Al}(\mathrm{OH})_{6}\right] \cdot 1 / 2 \mathrm{SeO}_{3} \cdot 3 \mathrm{H}_{2} \mathrm{O}$.

\begin{tabular}{|c|c|c|c|c|c|}
\hline Atom & Site & $x$ & $y$ & $z$ & Occupancy \\
\hline \multicolumn{6}{|l|}{$P \overline{3}, \mathrm{Z}=2$} \\
\hline \multicolumn{6}{|c|}{$a=5.7752(9) \AA, c=19.300(9) \AA, V=560.0(6) \AA^{3}$} \\
\hline Al1 & $1 a$ & 0 & 0 & 0 & 1 \\
\hline $\mathrm{Al} 2$ & $1 b$ & 0 & 0 & $1 / 2$ & 1 \\
\hline Ca1 & $2 d$ & $2 / 3$ & $1 / 3$ & -0.030 & 1 \\
\hline $\mathrm{Ca} 2$ & $2 d$ & $2 / 3$ & $1 / 3$ & 0.470 & 1 \\
\hline $\mathrm{O} 1\left(\mathrm{OH}^{-}\right)$ & $6 g$ & 0.00 & -0.28 & -0.055 & 1 \\
\hline $\mathrm{O} 2\left(\mathrm{OH}^{-}\right)$ & $6 g$ & 0.27 & 0.27 & 0.558 & 1 \\
\hline $\mathrm{O} 3\left(\mathrm{H}_{2} \mathrm{O}\right)$ & $2 d$ & $2 / 3$ & $1 / 3$ & -0.160 & 1 \\
\hline $\mathrm{O} 4\left(\mathrm{H}_{2} \mathrm{O}\right)$ & $2 d$ & $2 / 3$ & $1 / 3$ & 0.340 & $1 / 2$ \\
\hline $\mathrm{Se}$ & $6 g$ & 0.93 & 0.38 & 0.32 & $1 / 6$ \\
\hline $\mathrm{O} 5\left(\mathrm{SeO}_{3}\right)$ & $6 g$ & 0.00 & 0.65 & 0.37 & $1 / 6$ \\
\hline $\mathrm{O} 6\left(\mathrm{SeO}_{3}\right)$ & $6 g$ & 0.62 & 0.14 & 0.35 & $1 / 6$ \\
\hline $\mathrm{O} 7\left(\mathrm{SeO}_{3}\right)$ & $6 g$ & 0.86 & 0.47 & 0.24 & $1 / 6$ \\
\hline $\mathrm{O} 5\left(\mathrm{H}_{2} \mathrm{O}\right)$ & $2 c$ & 0 & 0 & 0.25 & $1 / 2$ \\
\hline
\end{tabular}



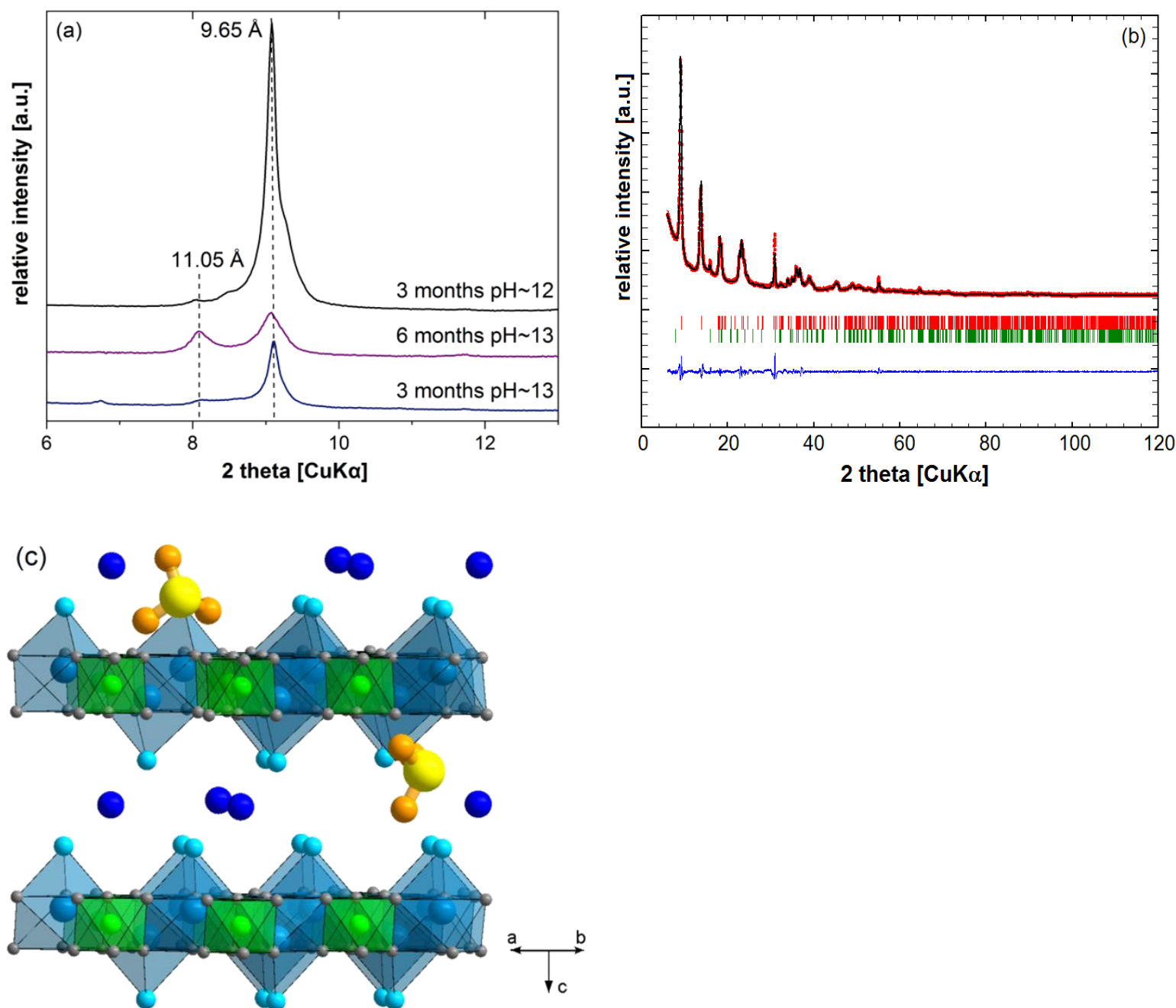

Figure 4: (a) XRPD pattern of the Se(IV)-AFm phase synthesized at different $\mathrm{pH}$. The samples were dried over a saturated $\mathrm{NaOH}$-solution (RH $~ 8 \%$ ). (b) Rietveld plot of the Se(IV)-AFm sample (pH 12) showing the diffraction experimental pattern (red dots), the calculated pattern (black line), the difference curve (blue line) and sticks for Bragg peaks position for the two Se(IV)-AFm hydrates with the interlayer distance $9.65 \AA$ (red) and $11.05 \AA$ (green). (c) General representation of the suggested structural model for the $9.65 \AA$ hydrate, projection almost along [110]. The $\mathrm{SeO}_{3}{ }^{2-}$ anion is shown in yellow and orange, the Ca polyhedra in light blue, Al octahedra in green, hydroxyl in grey, bonded water from the main layer in light blue and interlayer water molecules in dark blue. For clarity reasons, the disordered interlayer part of the structure is presented in an ordered way. 
with numerous diffraction peaks corresponding to a symmetry lower than rhombohedral or trigonal.

The diffraction pattern correlates to an apparent monoclinic lattice with the following refined parame-

ters: $a=10.5741(4) \AA, b=4.9846(2) \AA, c=8.6316(3) \AA$ and $\beta=105.759(4)^{\circ}$, and an interlayer distance of $10.18 \AA$. However, the monoclinic unit cell volume of $438 \AA^{3}$ for the interlayer distance of $10.18 \AA$ corresponds to a composition $1.5\left[\mathrm{Ca}_{2} \mathrm{Al}(\mathrm{OH})_{6}\right] \cdot \frac{1}{2} \mathrm{SeO}_{4} \cdot n \mathrm{H}_{2} \mathrm{O}$ which is inconsistent with crystallographic considerations. Attempts to solve the structure using a lower-symmetry triclinic unit cell were inconclusive and no other set of lattice parameters could be found with X-Cell [33]. At this stage single crys-
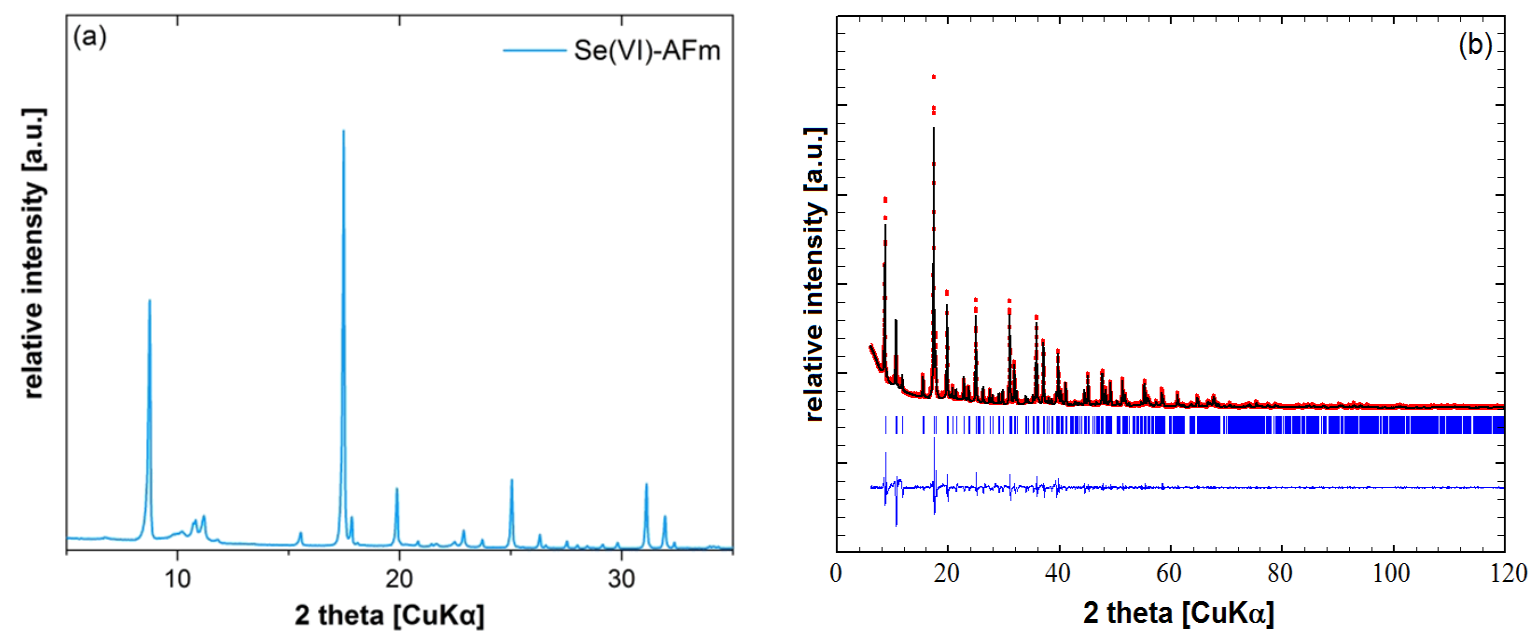

Figure 5: (a) XRPD pattern and (b) Rietveld plot of the Se(VI)-AFm sample using the monoclinic lattice parameters. 

structure with an interlayer distance of $10.33 \AA$. However, a diffraction peak cluster at $\sim 11^{\circ}$ was observed which cannot be explained by a rhombohedral symmetry. The use of a monoclinic unit cell with the lattice parameters $a=10.469(1) \AA, b=5.7736(7) \AA, c=9.982(1) \AA$ and $\beta=98.964(8)^{\circ}$ partially explains this diffraction peak cluster (Fig. 6). This monoclinic unit cell is related to the monoclinic structure of Friedel's salt.

Since this monoclinic lattice explains only partially the diffraction peaks, and since no structural model could be found in the monoclinic symmetry, structure solution using FOX has been performed into the average rhombohedral lattice. $\mathrm{S}_{2} \mathrm{O}_{3}{ }^{2-}$ geometry has been fixed to $\mathrm{S}-\mathrm{S}$ bond distance of $2.10 \AA$, S-O bond distance of $1.55 \AA$, S-S-O angles of $103^{\circ}$ and O-S-O angles of $107^{\circ}$. Invariably, obtained structure solutions indicate a perpendicular orientation of the $\mathrm{S}_{2} \mathrm{O}_{3}{ }^{2-}$ anion with the end-sulfur atom directed toward calcium cation. Although the structure solution models suggest an inclination of the S-S bond toward the trigonal axis, structure parameters gathered in Table 3 correspond to an average configuration with a more symmetrical situation: $\mathrm{S}_{2} \mathrm{O}_{3}{ }^{2-}$ oriented along the trigonal axis with both sulfur atom in a special $6 c$ Wyckoff site; i.e. with a perfectly normal orientation to the main layer. 
Table 3: Average - unrefined - structure solution proposed by FOX for the S(II)-AFm phase of compo-

433 sition $\left[\mathrm{Ca}_{2} \mathrm{Al}(\mathrm{OH})_{6}\right] \cdot 1 / 2 \mathrm{~S}_{2} \mathrm{O}_{3} \cdot 3 \mathrm{H}_{2} \mathrm{O}$.

\begin{tabular}{|c|c|c|c|c|c|}
\hline Atom & Site & $x$ & $y$ & $z$ & Occupancy \\
\hline \multicolumn{6}{|l|}{$R \overline{3}, \mathrm{Z}=3$} \\
\hline \multicolumn{6}{|c|}{$a=5.7660(6) \AA, c=30.9821(6) \AA, V=892.1(4) \AA^{3}$} \\
\hline $\mathrm{Al}$ & $3 a$ & 0 & 0 & 0 & 1 \\
\hline $\mathrm{Ca}$ & $6 c$ & $2 / 3$ & $1 / 3$ & 0.016 & 1 \\
\hline $\mathrm{O} 1\left(\mathrm{OH}^{-}\right)$ & $18 f$ & 0.2916 & 0.2493 & 0.035 & 1 \\
\hline $\mathrm{O} 2\left(\mathrm{H}_{2} \mathrm{O}\right)$ & $6 c$ & $2 / 3$ & $1 / 3$ & 0.100 & $3 / 4$ \\
\hline $\mathrm{O} 3\left(\mathrm{H}_{2} \mathrm{O}\right)$ & $6 c$ & $1 / 3$ & $2 / 3$ & 0.167 & $3 / 4$ \\
\hline S1 & $6 c$ & $2 / 3$ & $1 / 3$ & 0.100 & $1 / 4$ \\
\hline S2 & $6 c$ & $2 / 3$ & $1 / 3$ & 0.167 & $1 / 4$ \\
\hline $\mathrm{O} 4\left(\mathrm{~S}_{2} \mathrm{O}_{3}\right)$ & $18 f$ & 0.902 & 0.306 & 0.186 & $1 / 4$ \\
\hline
\end{tabular}

434

435

436

437

438

439 

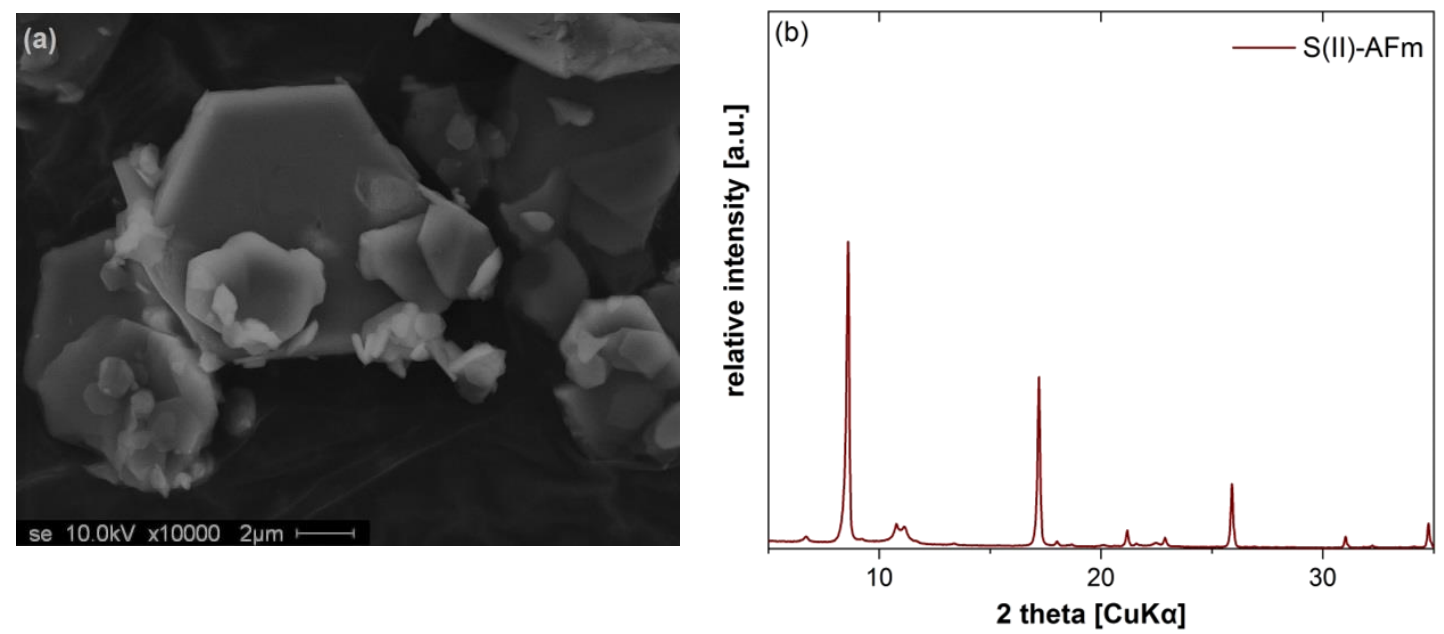

440
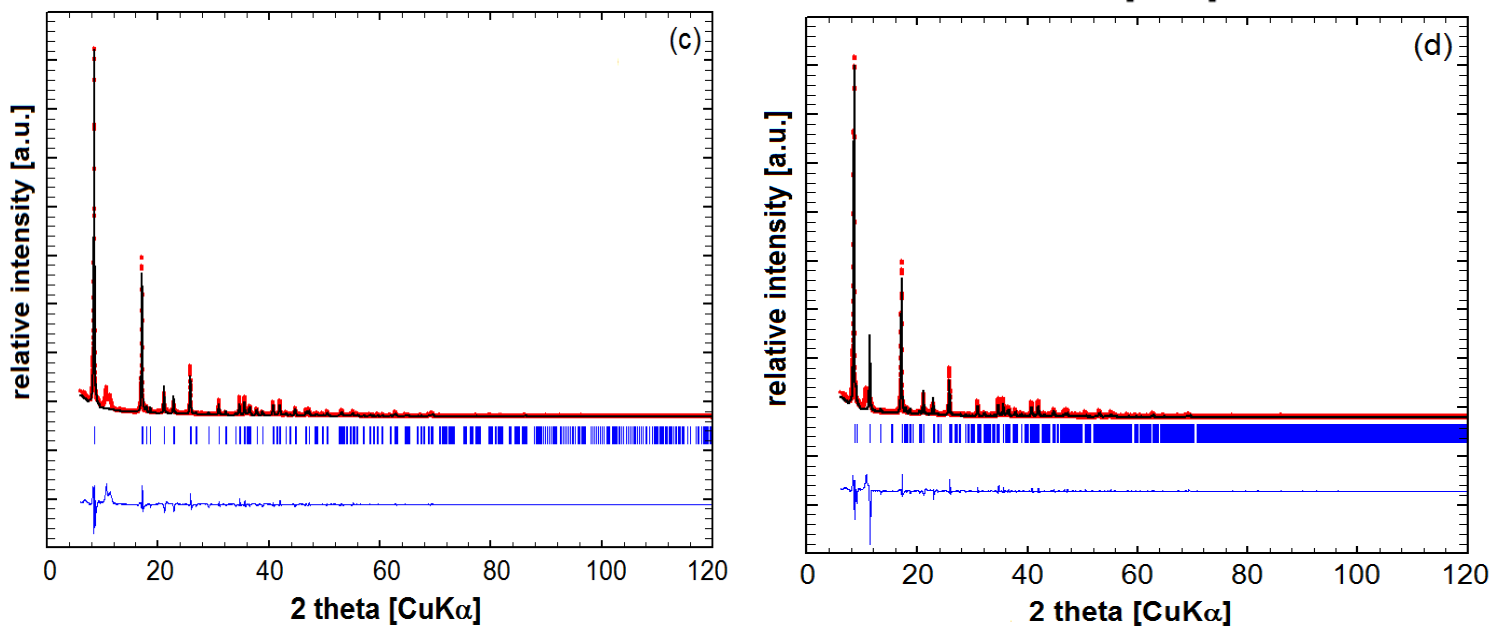

442

Figure 6: (a) SEM image of the S(II)-AFm showing the typical lamellar shape; XRPD pattern (b) and

Rietveld plot of the S(II)-AFm sample using a hexagonal (c) and a monoclinic (d) unit cell. 
Table 4: Summary of crystallographic data for the S- and Se-containing AFm phases.

\begin{tabular}{ccccccc}
\hline \hline AFm Phase & Empirical & System & Z & Cell Volume & Interlayer Distance & Density \\
& Formula & & & {$\left[\AA^{3}\right]$} & {$\left[\AA^{3}\right]$} & {$\left[\mathrm{g} / \mathrm{cm}^{3}\right]$} \\
\hline $\mathrm{S}(\mathrm{VI})^{[25]}$ & $\mathrm{AlCa}_{2} \mathrm{H}_{12} \mathrm{O}_{11} \mathrm{~S}_{0.5}$ & rhombohedral & 3 & 769.50 & 8.93 & 2.02 \\
$\mathrm{~S}(\mathrm{IV})$ & $\mathrm{AlCa} \mathrm{H}_{10.2} \mathrm{O}_{9.6} \mathrm{~S}_{0.5}$ & rhombohedral & 3 & $736.0(1)^{*}$ & $8.51^{*}$ & $1.94^{*}$ \\
$\mathrm{Se}(\mathrm{IV})$ & $\mathrm{AlCa}_{2} \mathrm{H}_{12} \mathrm{O}_{10} \mathrm{Se}_{0.5}$ & trigonal & 2 & $560.0(6)^{*}$ & $9.65^{*}$ & $1.94^{*}$ \\
$\mathrm{Se}(\mathrm{VI})$ & $\mathrm{AlCa}_{2} \mathrm{H}_{12} \mathrm{O}_{11} \mathrm{Se}_{0.5}$ & monoclinic* & 1.5 & $(438)^{*}$ & $10.18^{*}$ & $1.90^{*}$ \\
$\mathrm{~S}(\mathrm{II})$ & $\mathrm{AlCa}_{2} \mathrm{H}_{12} \mathrm{O}_{10.5} \mathrm{~S}$ & rhombohedral & 3 & $892.1(4)^{*}$ & $10.33^{*}$ & $1.78^{*}$ \\
\hline \hline
\end{tabular}

* tentative values based on the best structural model found from the XRPD data.

\subsection{Water in the AFm phases:}

The binding of water in the synthesized AFm phases was investigated by several techniques. with sulfur decomposition and loss of $\mathrm{CO}_{2}\left(\right.$ at $\sim 700^{\circ} \mathrm{C}$ ), which is present in minor amounts due to atmospheric contamination ( $<1.5 \mathrm{wt} . \%)$. Therefore, weight loss above $600^{\circ} \mathrm{C}$ was not taken into consideration.

The TGA-DTG curves (Fig. 7) of all synthesized samples show stepwise water removal, which was observed in the temperature regions characteristic for AFm phases [45]. Loosely bound water from the interlayer is lost in three temperature steps which vary in size and range for the different samples. In general, however, water removal from the interlayer occurs up to a temperature of $\sim 250^{\circ} \mathrm{C}$. In the temperature region between $250^{\circ} \mathrm{C}$ and $600^{\circ} \mathrm{C}$ the six main layer waters of $\mathrm{Ca}_{4} \mathrm{Al}_{2}(\mathrm{OH})_{12}{ }^{2+}$ are lost. $\mathrm{A}$ weight loss at $\sim 450^{\circ} \mathrm{C}$ indicates the presence of portlandite impurities as found in the S(IV)-AFm. The 


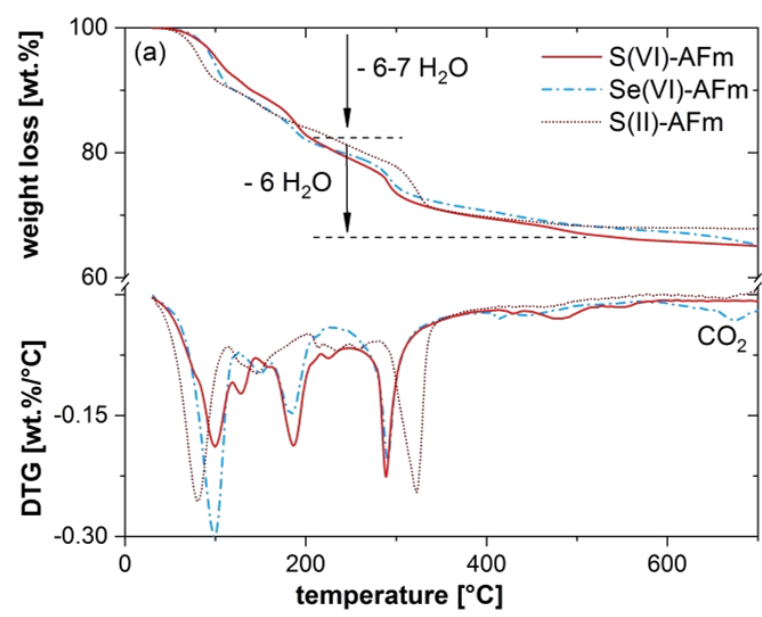

total mass losses add up to $~ 30$ wt.\% for S(IV)-AFm, 32 wt.\% for Se(IV)-AFm, 33 wt.\% for S(II)- and $\mathrm{Se}(\mathrm{VI})-\mathrm{AFm}$, and $\sim 35$ wt.\% for $\mathrm{S}(\mathrm{VI})-\mathrm{AFm}$. The number of $\mathrm{H}_{2} \mathrm{O}$ molecules was calculated as $\sim 11 \mathrm{H}_{2} \mathrm{O}$ for S(IV)- and Se(IV)-AFm, $\sim 12 \mathrm{H}_{2} \mathrm{O}$ for S(VI)-AFm, and $\sim 13 \mathrm{H}_{2} \mathrm{O}$ for S(II)- and Se(VI)-AFm, respectively.
478

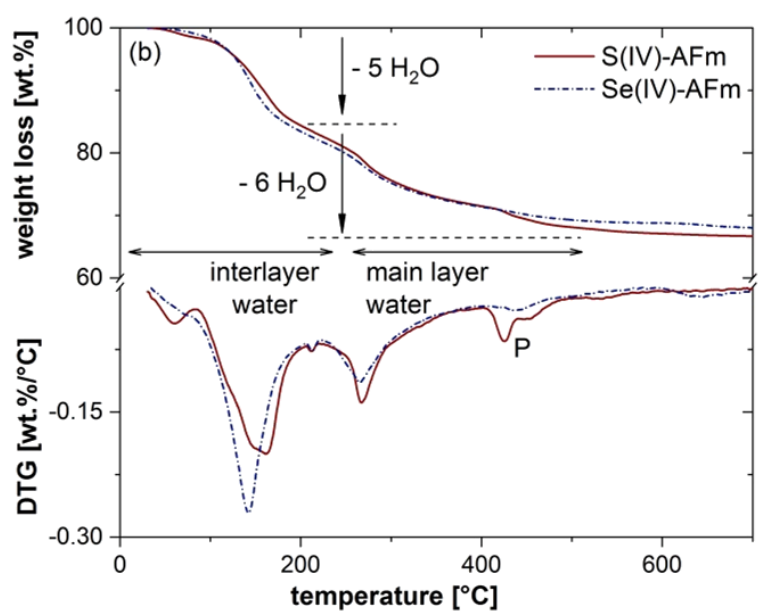

Figure 7: TGA data for the studied AFm phases synthesized at $\mathrm{pH} 13$. The samples were dried over a saturated $\mathrm{NaOH}$ solution (RH 8 \%). P: portlandite.

3.2.2 FTIR/Raman spectra: Figure 8 shows the FTIR spectra recorded between 600 and 4000 $\mathrm{cm}^{-1}$ and the Raman spectra recorded between 55 and $3700 \mathrm{~cm}^{-1}$ of the samples.

To better understand the FTIR and Raman spectra of the interlayer anions, the observed peak positions are compared with literature data for the free anions in solution [46-48] to detect possible changes in the spectral behaviour caused by the structural environment in the AFm phase (Table 5). The assignment of the peak positions of the anions was also verified by comparison with FTIR measurements on the $\mathrm{Na}_{2}$-sulfur salts used for the synthesis. In carbonate $\left(\mathrm{CO}_{3}{ }^{2-}\right)$ containing AFm phases, for instance, two band positions for the Raman-active symmetric stretching mode $\left(v_{1}\right)$ can be found: an absorption band at $\sim 1086 \mathrm{~cm}^{-1}$ is characteristic for a weakly bonded $\mathrm{CO}_{3}{ }^{2-}$ in the centre of the interlayer; while in 
the cases where the carbonate is bonded to the main layer (via a Ca) a shift towards lower wavenumbers is observed and the $V_{1}\left(\mathrm{CO}_{3}{ }^{2-}\right)$ vibration occurs at $\sim 1068 \mathrm{~cm}^{-1}[16]$.

The free $\mathrm{SO}_{4}{ }^{2-}$ and $\mathrm{SeO}_{4}{ }^{2-}$ anions have a $\mathrm{T}_{\mathrm{d}}$ symmetry with the symmetric stretching mode $\mathrm{V}_{1}$ and bending mode $v_{2}$ Raman active only and the asymmetric stretching mode $v_{3}$ and bending mode $v_{4}$ both FTIR and Raman active [46]. In monosulfate, due to the interactions with the crystal structure, the point symmetry of $\mathrm{SO}_{4}{ }^{2-}$ is lowered, leading to the splitting of the $v_{1}$ and $v_{3}$ modes into two components: $v_{1}, v_{1}, v_{3}$ and $v_{3}$, respectively [49]. In the FTIR spectrum of the S(VI)-AFm (Figure 8a), the $v_{3}$ is visible as a strong, broad absorption peak at $\sim 1100 \mathrm{~cm}^{-1}$ with a shoulder at $\sim 1160 \mathrm{~cm}^{-1}\left(v_{3}{ }^{3}\right)$. A very weak absorption band at $\sim 620 \mathrm{~cm}^{-1}$ is also observed, which could be attributed to the $v_{4}$ mode. The Raman spectrum of the phase shows the $v_{1}$ at $\sim 982 \mathrm{~cm}^{-1}$; with a shoulder at $\sim 990 \mathrm{~cm}^{-1}$ belonging to the $v_{1}$ ' component. The $v_{2}$ and $v_{4}$ modes are present at $\sim 450$ and $\sim 615 \mathrm{~cm}^{-1}$, respectively; at positions similar to the ones of the free $\mathrm{SO}_{4}{ }^{2-}$ anion. The $\sqrt{3}_{3}$ absorption band cannot be clearly distinguished; however, a broad, low intensity band is observed between 1090 and $1160 \mathrm{~cm}^{-1}$, suggesting splitting of the $v_{3}$ band. The $v_{3}\left(\mathrm{SeO}_{4}^{2-}\right)$ mode in the $\mathrm{Se}(\mathrm{VI})-\mathrm{AFm}$ is visible at $\sim 874 \mathrm{~cm}^{-1}$ by FTIR and $\sim 870 \mathrm{~cm}^{-1}$ by Raman, where it overlaps with the symmetric stretching $v_{1}$ mode $\left(\sim 835 \mathrm{~cm}^{-1}\right)$. The two signals at $\sim 335$ and $\sim 395 \mathrm{~cm}^{-1}$ are most probably caused by the bending $v_{2}$ and $v_{4}$ modes, occurring thus at slightly lower wavenumbers than expected for the free $\mathrm{SeO}_{4}{ }^{2-}\left(v_{2}: \sim 345 \mathrm{~cm}^{-1}\right.$ and $v_{4}: \sim 412 \mathrm{~cm}^{-1}$ [47]).

Free $\mathrm{SO}_{3}{ }^{2-}$ and $\mathrm{SeO}_{3}{ }^{2-}$ anions have $\mathrm{C}_{3 \mathrm{v}}$ point symmetry with the four normal modes both FTIR and Raman active [46]. In the $\mathrm{S}(\mathrm{IV})-\mathrm{AFm}$, the $\mathrm{v}_{3}\left(\mathrm{SO}_{3}{ }^{2-}\right)$ mode is seen in FTIR as a very broad, asymmetric absorption band at $\sim 955 \mathrm{~cm}^{-1}$, possibly caused by overlapping with the $v_{1}$ band (at $\sim 967 \mathrm{~cm}^{-1}$ for the free $\mathrm{SO}_{3}{ }^{2-}$ [48]) and/or by splitting. The FTIR spectrum of the phase is further characterized by another broad band, consisting of at least two overlapping components at $\sim 695$ and $745 \mathrm{~cm}^{-1}$ (Figure 8c). In Raman the bending $v_{2}$ and $v_{4}$ modes occur as weak signals at $\sim 620$ and $\sim 480 \mathrm{~cm}^{-1}$; while the overlapping bands at $\sim 975$ and $\sim 995 \mathrm{~cm}^{-1}$ are most probably due to the $v_{1}$ and $v_{3}$ modes. The $v_{3}$ mode in the $\mathrm{Se}$ (IV)-AFm is observed in FTIR at $\sim 730 \mathrm{~cm}^{-1}$ with a shoulder at $\sim 800 \mathrm{~cm}^{-1}$ corresponding to the $V_{1}$ mode. In Raman, the two modes are observed in the same positions with additional shoulder at $\sim 780$ 
$517 \mathrm{~cm}^{-1}$ indicating splitting of the $v_{1}$ band. The $v_{4}$ mode is visible at $\sim 374 \mathrm{~cm}^{-1}$; the $v_{2}$ at $\sim 455 \mathrm{~cm}^{-1}$, which 518 implies a slight shift of the $v_{2}$ mode to higher wavenumbers.

519 The free $\mathrm{S}_{2} \mathrm{O}_{3}{ }^{2-}$ anion has a $\mathrm{C}_{3 \mathrm{v}}$ point symmetry with six FTIR and Raman active vibrational modes [46]. 520 All six bands can be identified in the Raman spectrum of the S(II)-AFm, appearing at positions close to 521 the ones expected for the free $\mathrm{S}_{2} \mathrm{O}_{3}{ }^{2-}$ anion with exception of the $\mathrm{V}_{2}$ mode, which seems to be shifted towards lower wavenumbers at $\sim 630 \mathrm{~cm}^{-1}$ compared to $669 \mathrm{~cm}^{-1}$ for $\mathrm{S}_{2} \mathrm{O}_{3}{ }^{2-}$ measured in solution [47]. In FTIR, however, the $v_{2}$ band is observed without a shift at $\sim 670 \mathrm{~cm}^{-1}$, together with the $v_{1}\left(\sim 1010 \mathrm{~cm}^{-}\right.$ $\left.{ }^{1}\right)$ and $\vee_{4}\left(\sim 1130 \mathrm{~cm}^{-1}\right)$ modes as well as a shoulder at $\sim 1070 \mathrm{~cm}^{-1}$ (Figure 8e).

Two types of hydrous components can be distinguished in the FTIR spectra of the samples. Interlayer $\mathrm{H}_{2} \mathrm{O}$ is visible by absorption bands in the $3600-3000 \mathrm{~cm}^{-1}$ and in the $1650-1600 \mathrm{~cm}^{-1}$ region. Less resolved spectra between 3600 and $3000 \mathrm{~cm}^{-1}$ indicate disorder in the interlayer [49]. Such is the case with the $\mathrm{S}(\mathrm{VI})-$, the $\mathrm{Se}(\mathrm{VI})$ - and the $\mathrm{S}(\mathrm{II})-\mathrm{AFm}$ phases. In contrast, better ordered interlayer water is indicated in case of the S(IV)- and the Se(IV)-AFm. The water from the main layer, on the other hand, is visible by absorption at $\sim 3670-3650 \mathrm{~cm}^{-1}$, which is attributed to the hydroxyl symmetric stretching mode. In the Raman spectra similar patterns can be observed. The broad signal at $\sim 2800-3600 \mathrm{~cm}^{-1}$ is attributed to water bonded in the interlayer, whereas the sharp peak at $\sim 3688 \mathrm{~cm}^{-1}$ is caused by the $\mathrm{OH}$ groups from the main layer [49]. The band position for $\mathrm{Al}(\mathrm{OH})_{6}$ appears at $\sim 532 \mathrm{~cm}^{-1}$ for all investigated samples as also observed for other AFm phases $[16,49]$. The small absorption bands at $1450-$ $1250 \mathrm{~cm}^{-1}$ in the FTIR and at $\sim 1086 \mathrm{~cm}^{-1}$ in the Raman spectra corresponds to weakly bound carbonate in the interlayer indicating minor $\mathrm{CO}_{2}$ contamination.

(1)


542 Table 5: Summary of the main vibrational frequencies observed in the FTIR and Raman spectra of the

543 synthesized AFm phases; as well as comparison with literature data for the free $\mathrm{SO}_{4}{ }^{2-}, \mathrm{SeO}_{4}{ }^{2-}, \mathrm{SO}_{3}{ }^{2-}$,

$544 \mathrm{SeO}_{3}{ }^{2-}$ and $\mathrm{S}_{2} \mathrm{O}_{3}{ }^{2-}$ anions.

\begin{tabular}{|c|c|c|c|c|c|c|c|}
\hline Species & $\begin{array}{c}v_{1} \\
{\left[\mathrm{~cm}^{-1}\right]}\end{array}$ & $\begin{array}{c}v_{2} \\
{\left[\mathrm{~cm}^{-1}\right]}\end{array}$ & $\begin{array}{c}v_{3} \\
{\left[\mathrm{~cm}^{-1}\right]}\end{array}$ & $\begin{array}{c}\mathrm{V}_{4} \\
{\left[\mathrm{~cm}^{-1}\right]}\end{array}$ & $\begin{array}{c}v_{5} \\
{\left[\mathrm{~cm}^{-1}\right]}\end{array}$ & $\begin{array}{c}v_{6} \\
{\left[\mathrm{~cm}^{-1}\right]}\end{array}$ & Method \\
\hline $\mathrm{SO}_{4}{ }_{(\mathrm{aq})^{2-}}^{[46]}$ & 983 & 450 & 1105 & 611 & & & FTIR/Raman \\
\hline $\mathrm{S}(\mathrm{VI})-\mathrm{AFm} \mathrm{m}^{\text {t.s. }}$ & - & n.d. & $1100 / 1160$ & 620 & & & FTIR \\
\hline $\mathrm{S}(\mathrm{VI})-\mathrm{AFm}{ }^{[49], \text { t.s. }}$ & $982 / 990$ & 450 & $1090 / 1160$ & 615 & & & Raman \\
\hline $\mathrm{SeO}_{4}^{2-}(\mathrm{aq})^{[47]}$ & 832 & 345 & 879 & 412 & & & FTIR/Raman \\
\hline $\mathrm{Se}(\mathrm{VI})-\mathrm{AFm} \mathrm{m}^{\text {t.s. }}$ & & n.d. & 874 & n.d. & & & FTIR \\
\hline $\mathrm{Se}(\mathrm{VI})-\mathrm{AFm} \mathrm{m}^{\text {t.s. }}$ & 835 & $335 ?$ & 870 & $395 ?$ & & & Raman \\
\hline $\mathrm{S}_{2} \mathrm{O}_{3}{ }^{2-}{ }_{(\mathrm{aq})}^{[47]}$ & 995 & 669 & 446 & 1123 & 541 & 335 & FTIR/Raman \\
\hline $\mathrm{S}(\mathrm{II})-\mathrm{AFm} \mathrm{ts.}^{\mathrm{ts} .}$ & 1010 & 670 & n.d. & 1130 & n.d. & n.d. & FTIR \\
\hline $\mathrm{S}(\mathrm{II})-\mathrm{AFm} \mathrm{m}^{\mathrm{t} . \mathrm{s} .}$ & 995 & 630 & 442 & 1125 & 541 & 327 & Raman \\
\hline $\mathrm{SO}_{3}{ }_{(\mathrm{aq})^{2-}}^{[48]}$ & 967 & 620 & 933 & 469 & & & FTIR/Raman \\
\hline$S(I V)-A F m^{\text {t.s. }}$ & - & - & 955 & n.d. & & & FTIR \\
\hline $\mathrm{S}(\mathrm{IV})-\mathrm{AFm} \mathrm{m}^{\text {t.s. }}$ & $995 ?$ & 620 & $975 ?$ & 480 & & & Raman \\
\hline $\mathrm{SeO}_{3}{ }^{2-}(\mathrm{aq})^{[47]}$ & 807 & 432 & 737 & 374 & & & FTIR/Raman \\
\hline Se(IV)-AFm ${ }^{\text {t.s. }}$ & 800 & n.d. & 730 & n.d. & & & FTIR \\
\hline $\mathrm{Se}(\mathrm{IV})-\mathrm{AFm}{ }^{\text {t.s. }}$ & $780 / 800$ & 455 & 730 & 374 & & & Raman \\
\hline $\mathrm{Al}(\mathrm{OH})_{6}^{[16,49], \text { t.s. }}$ & & 532 & & & & & Raman \\
\hline $\mathrm{H}_{2} \mathrm{O}$ interlayer ${ }^{[49], \text { t.s. }}$ & $3000-3600$ & $1600-1650$ & & & & & FTIR/Raman \\
\hline $\mathrm{OH}$ main layer ${ }^{[49], \text { t.s. }}$ & $3650-3670$ & & & & & & FTIR/Raman \\
\hline $\mathrm{CO}_{3}^{2-[16], \text { t.s. }}$ & 1086 & & $1250-1450$ & & & & FTIR/Raman \\
\hline
\end{tabular}

545

n.d.: no data; t.s.: this study 

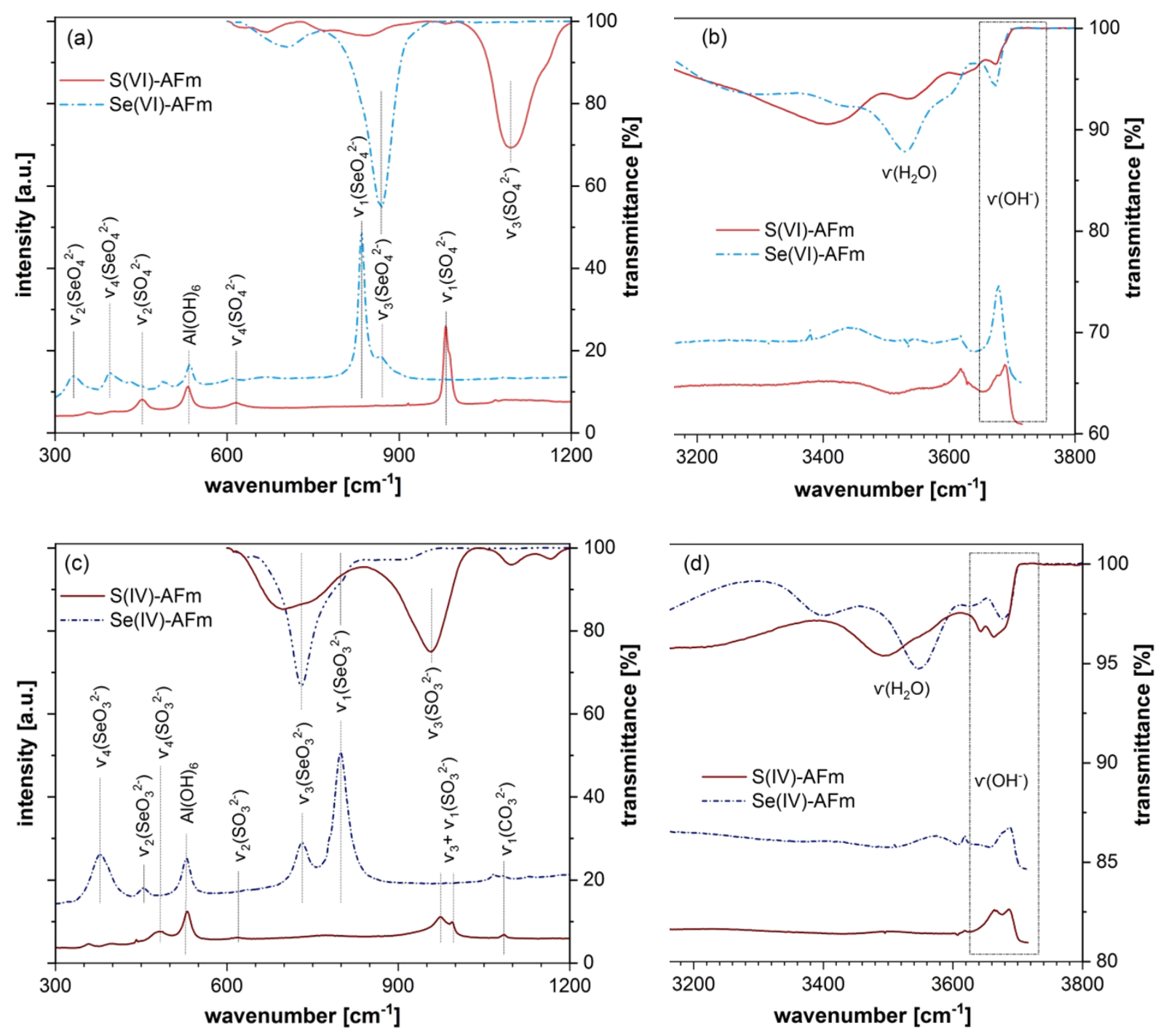

547
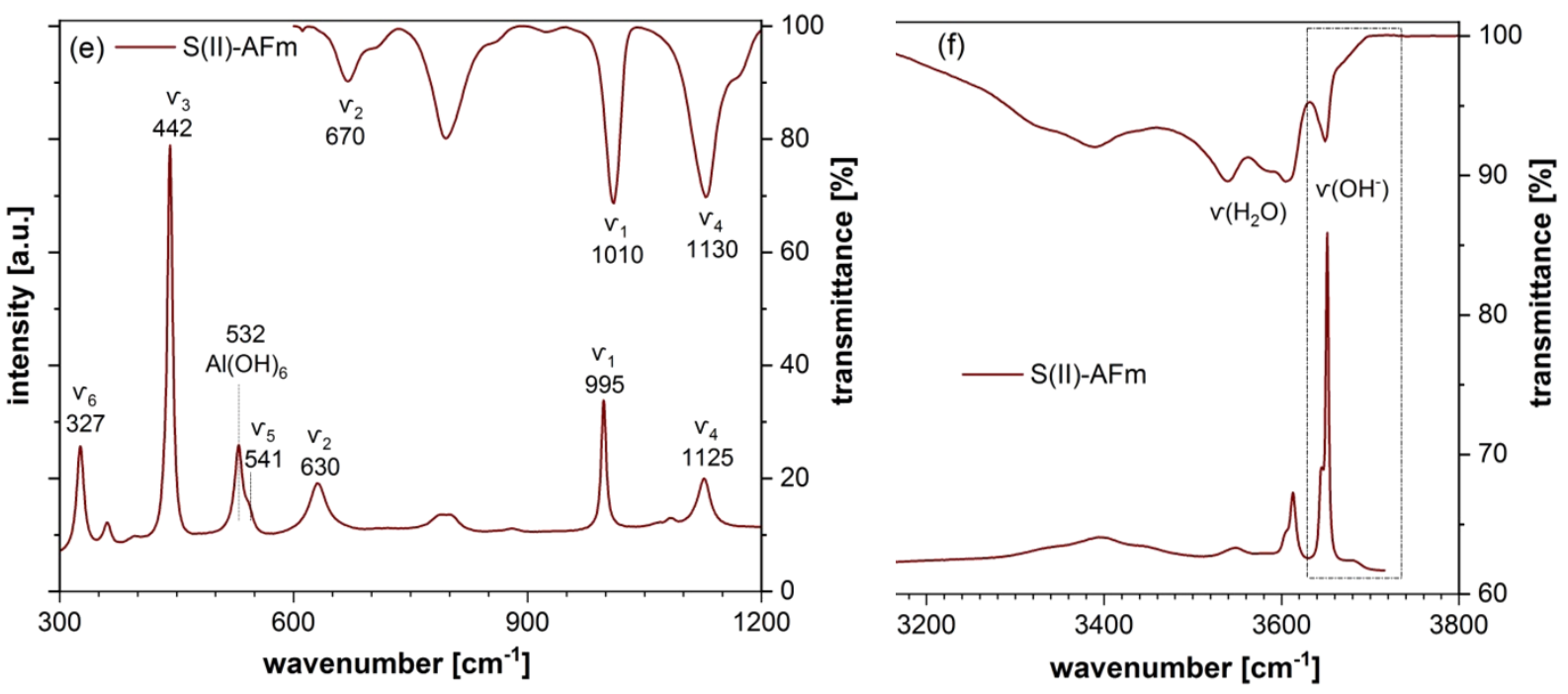

Figure 8: FTIR (top) and Raman (bottom) spectra of the synthesized AFm phases in the frequencies ranges of the interlayer anions $\left(300-1200 \mathrm{~cm}^{-1}\right)$ and the hydrogen bond network $\left(3200-3800 \mathrm{~cm}^{-1}\right)$. 
553 The FTIR and Raman spectra confirm the presence of AFm phases with their typical $\mathrm{Al}(\mathrm{OH})_{6}$-vibration in 554 the $\sim 530 \mathrm{~cm}^{-1}$ region (Raman shift) and further allow the different interlayer ions to be identified. No 555 clear conclusions can be made regarding the orientation of the interlayer anions to either confirm or disregard the proposed structural arrangements for the studied AFm phases.

3.2.3 DVS: Based on the initial composition obtained by TGA, the change of the hydration level of the samples as a function of the relative humidity was examined. The sorption experiments were carried out on samples which had been stored for 1 year in a desiccator over a saturated $\mathrm{NaOH}$ solution (RH 8\%). The data were normalized to the water content determined by TGA at $8 \%$ RH for each sample.

The DVS of the S(VI)-AFm has been detailed in Baquerizo et al. [26]. The $\mathrm{S}(\mathrm{VI})$-AFm contains $10.5 \mathrm{H}_{2} \mathrm{O}$ per formula unit below $~ 30 \% \mathrm{RH}, 12 \mathrm{H}_{2} \mathrm{O}$ between 30 and $97 \% \mathrm{RH}$ and $14 \mathrm{H}_{2} \mathrm{O}$ above $97 \% \mathrm{RH}$. The S(II)-AFm shows only a single absorption step at low RH and no further changes (Fig. 9). At $5 \%$ RH a 9 $\mathrm{H}_{2} \mathrm{O}$ hydrate is observed, which transforms to a $13 \mathrm{H}_{2} \mathrm{O}$ hydrate at $30 \% \mathrm{RH}$ and dehydrates back to 9 $\mathrm{H}_{2} \mathrm{O}$ between 10 and $20 \% \mathrm{RH}$ in the desorption cycle. For the Se(IV)-AFm a stable hydration state of $11 \mathrm{H}_{2} \mathrm{O}$ was observed which shows no changes with increasing $\mathrm{RH}$. The minimal total water content achieved for the $\mathrm{Se}(\mathrm{VI})-\mathrm{AFm}$ is $12 \mathrm{H}_{2} \mathrm{O}$ at $5 \% \mathrm{RH}$. The hydration state of the sample increases to 13 $\mathrm{H}_{2} \mathrm{O}$ at $10 \% \mathrm{RH}$ and remains stable up to $95 \% \mathrm{RH}$. Desorption occurs at $10 \% \mathrm{RH}$. For the S(IV)-AFm phase an initial hydration state of $11 \mathrm{H}_{2} \mathrm{O}$ is observed, which remains stable up to $70 \% \mathrm{RH}$ (Fig. 10). Between 70 and $95 \% \mathrm{RH}$ the sample undergoes a steady water uptake reaching $40 \mathrm{H}_{2} \mathrm{O}$ at $95 \% \mathrm{RH}$ and dehydrates back to $11 \mathrm{H}_{2} \mathrm{O}$ at $70 \% \mathrm{RH}$. Due to the unusually high hydration level observed, a second measurement was performed on the S(IV)-AFm sample to verify the acquired data, giving almost identical results. 
577 The sorption isotherms for the S(II)-AFm, Se(IV)-AFm and Se(VI)-AFm phases show a similar evolution

578 with a water decrease at lower $\mathrm{RH}(5-30 \% \mathrm{RH})$, followed by a plateau at higher $\mathrm{RH}$. This general

579 trend had also been observed for other AFm phases (S(VI)-AFm [26], monocarbonate, hemicarbonate

580 and hydroxy-AFm [27]). The high water uptake of the S(IV)-AFm at high RH could possibly be the result

581 of water condensation on the surface.

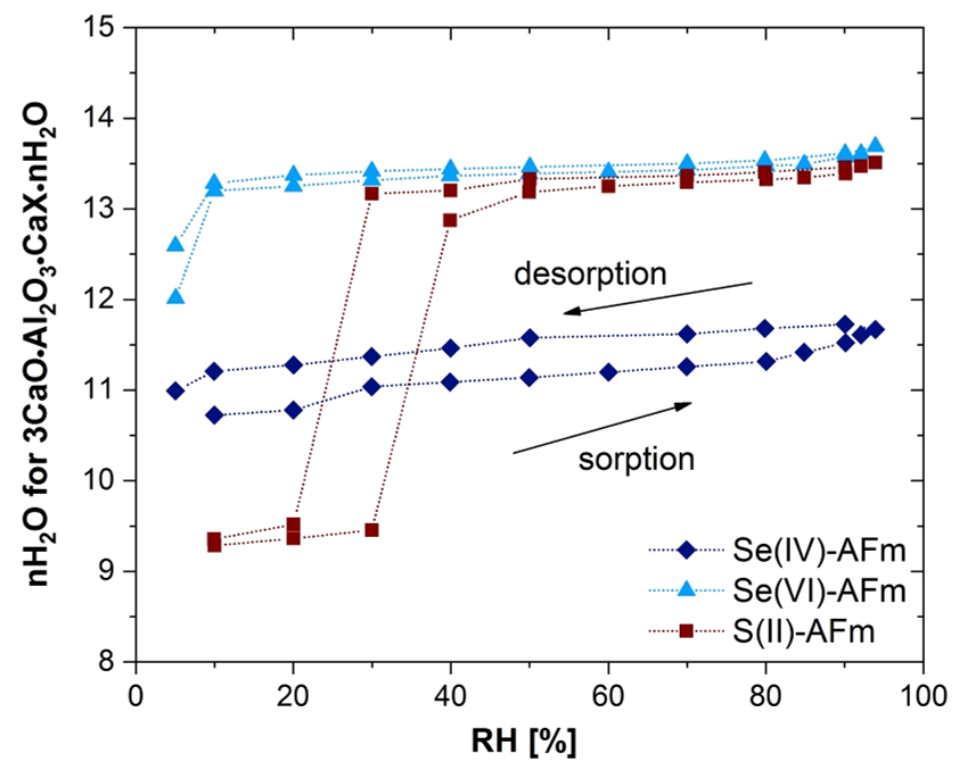

Figure 9: Sorption isotherms for the S(II)-, Se(IV)- and Se(VI)-AFm phases measured at $25^{\circ} \mathrm{C}$. The graph was normalized to the $\mathrm{n}_{2} \mathrm{O}$ determined by TGA at $8 \% \mathrm{RH}$ for each sample. 


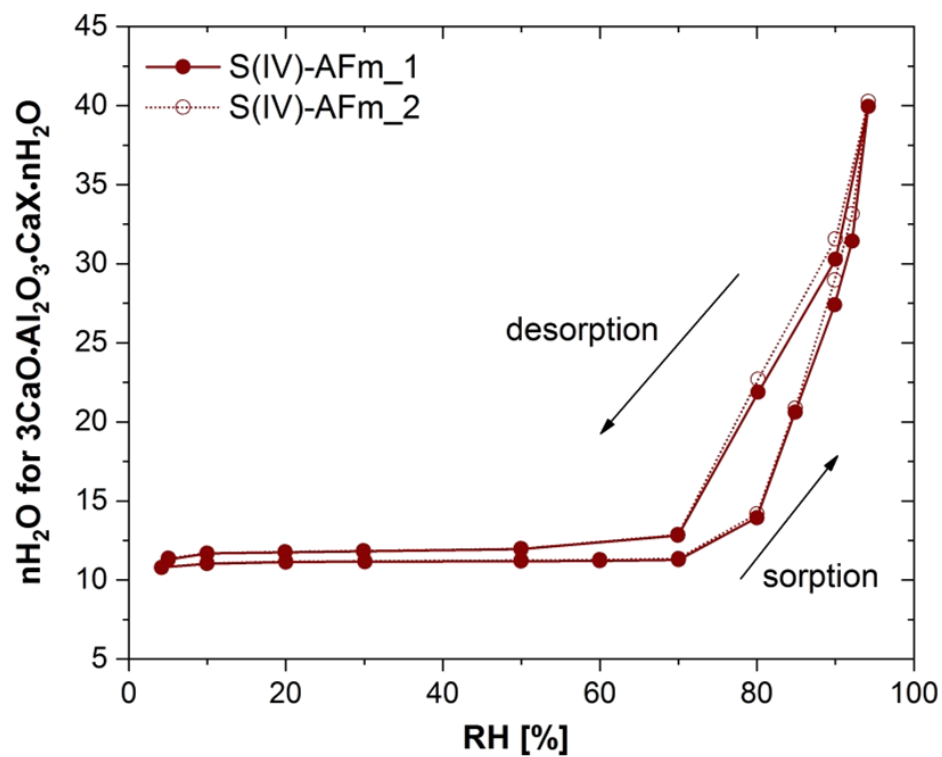

Figure 10: Sorption isotherms for the $\mathrm{S}(\mathrm{IV})-\mathrm{AFm}$ phase measured at $25^{\circ} \mathrm{C}$ showing the two measurements S(IV)-AFm_1 and S(IV)-AFm_2. The graph was normalized to the $11 \mathrm{H}_{2} \mathrm{O}$ determined by TGA at 8 $\%$ RH. dix A.1 and A.2) the solubility products for the different AFm phases were calculated. The solubility products are plotted in Figure 11 for different aging times (3 vs. 6 months) and different pH values ( $\mathrm{pH} \sim 13$ vs. $\mathrm{pH} \sim 12$ for the $\mathrm{S}(\mathrm{VI})-$ and the $\mathrm{Se}(\mathrm{IV})-\mathrm{AFm})$. For the calculations the highest hydration state of each phase as observed in the DVS measurements was used; solely for the S(IV)-AFm the high hydration state of $40 \mathrm{H}_{2} \mathrm{O}$, which is most probably due to water condensation on the surface, was neglected and the solubility product calculated with $11 \mathrm{H}_{2} \mathrm{O}$. The calculated solubility products (log $\mathrm{K}$ ) for all AFm phases are similar with mean values ranging between $-30.5 \pm 1.1$ (S(II)-AFm) and $-26.9 \pm 1.1$ (S(IV)-AFm) (Table 6). The S(IV)-AFm shows the least negative value suggesting thus that it is the least stable phase. The largest scatter in calculated solubility products was observed for the S(VI)-AFm with values between -27.5 to -30.2 and for the Se(IV)-AFm (-25.5 to -30.9). The solubility of the S(VI)-AFm 
to the formation of a solid solution between hydroxyl-AFm (OH-AFm) and S(VI)-AFm as discussed in detail by Matschei et al. [3]. A portion of the $\mathrm{SO}_{4}{ }^{2-}$ in the interlayer is substituted by $\mathrm{OH}^{-}$leading to the formation of an (S(VI)-OH)-AFm phase with an apparent higher solubility product, compared to pure $\mathrm{S}(\mathrm{VI})-\mathrm{AFm}$ (mean value for all measurements at $\mathrm{pH} 13 \log \mathrm{K}=-28.1 \pm 0.7$ compared to the solubility products obtained at $\mathrm{pH} \sim 12 \log \mathrm{K}=-30.2 \pm 0.7)$. The latter value is also closer to the values of -29.3 to -29.8 reported in recent literature $[14,19,50]$, where the solubility was also determined at $\mathrm{pH} \sim 12$. The solubility products determined for the Se(IV)-AFm are very similar with $-28.2 \pm 1.6$ at $\mathrm{pH} \sim 13$ and $28.5 \pm 0.7$ at $\mathrm{pH} \sim 12$. However, at the higher $\mathrm{pH}$, the scatter is relatively large which could be related to the lower degree of crystallinity of the samples at higher $\mathrm{pH}$ values as shown in Figure 4 . However, the solubility product of Se(IV)-AFm with $-28.4 \pm 0.8$ agrees well with the solubility of -28.1 recently determined by Ma et al. [41]. The Se(VI)-AFm has a solubility product of $-29.2 \pm 1.5$ showing the least scatter and agrees well with the value of -28.6 published earlier by Baur \& Johnson [51] within the error. The aging time seems to have no pronounced effect on the samples stability as the calculated solubility products after 6 months are comparable to those after 3 months within the errors.

The solubility products for S(VI)-, S(IV)-, S(II)-, Se(VI)- and Se(IV)-AFm phases are all similar with mean values of -26.9 to -30.5 . These solubility products are also comparable to the solubility of other AFm phases containing oxyanions, such as the -28.4 reported for $\mathrm{CrO}_{4}-\mathrm{AFm}$ [14] or -27.8 for $\mathrm{MoO}_{4}-\mathrm{AFm}$ [15]. These similar solubilities of the AFm phases with oxyanions suggest that the sulfur concentration in the pore solution of the cement will strongly affect Se binding by AFm phases; high sulfur concentration are expected to lower Se binding.

(1) 
653 Table 6: Mean solubility products (log K), Gibbs energy of formation $\left(\Delta_{\mathrm{f}} \mathrm{G}^{0}\right)$, enthalpy of formation $654\left(\Delta_{\mathrm{f}} \mathrm{H}^{0}\right)$, entropy $\left(\mathrm{S}^{0}\right)$, heat capacity $\left(\mathrm{C}_{\mathrm{p}}{ }^{0}\right)$ and molar volume $\left(\mathrm{V}^{0}\right)$ calculated for the synthesized AFm phas655 es at $20^{\circ} \mathrm{C}$ and 1 bar.

\begin{tabular}{|c|c|c|c|c|c|c|}
\hline Phase & $\log K$ & $\Delta_{\mathrm{f}} \mathrm{G}^{0}$ & $\Delta_{\mathrm{f}} \mathrm{H}^{0}$ & $S^{0}$ & $C_{p}^{0}$ & $\mathrm{~V}^{0}$ \\
\hline & & {$[\mathrm{kJ} / \mathrm{mol}]$} & {$[\mathrm{kJ} / \mathrm{mol}]$} & {$[\mathrm{J} / \mathrm{mol} \cdot \mathrm{K}]$} & {$[\mathrm{J} / \mathrm{mol} \cdot \mathrm{K}]$} & {$\left[\mathrm{cm}^{3} / \mathrm{mol}\right]$} \\
\hline $\mathrm{S}(\mathrm{VI})-\mathrm{AFm}$ & -28.8 & -8009 & -9031 & 891.0 & 1017.8 & $331^{[26]}$ \\
\hline $3 \mathrm{CaO} \cdot \mathrm{Al}_{2} \mathrm{O}_{3} \cdot \mathrm{CaSO}_{4} \cdot 14 \mathrm{H}_{2} \mathrm{O}$ & \pm 1.2 & & & & & \\
\hline $\mathrm{S}(\mathrm{IV})-\mathrm{AFm}$ & -26.9 & -7269 & -8178 & 703.0 & 852.2 & 295 \\
\hline $3 \mathrm{CaO} \cdot \mathrm{Al}_{2} \mathrm{O}_{3} \cdot \mathrm{CaSO}_{3} \cdot 11 \mathrm{H}_{2} \mathrm{O}$ & \pm 1.1 & & & & & \\
\hline $\mathrm{S}(\mathrm{II})-\mathrm{AFm}$ & -30.5 & -7795 & -8782 & 939.1 & 1045.4 & 358 \\
\hline $3 \mathrm{CaO} \cdot \mathrm{Al}_{2} \mathrm{O}_{3} \cdot \mathrm{CaS}_{2} \mathrm{O}_{3} \cdot 13 \mathrm{H}_{2} \mathrm{O}$ & \pm 1.1 & & & & & \\
\hline $\mathrm{Se}(\mathrm{VI})-\mathrm{AFm}$ & -29.2 & -7708 & -8729 & 905.1 & 1335.0 & 352 \\
\hline $3 \mathrm{CaO} \cdot \mathrm{Al}_{2} \mathrm{O}_{3} \cdot \mathrm{CaSeO}_{4} \cdot 13 \mathrm{H}_{2} \mathrm{O}$ & \pm 1.5 & & & & & \\
\hline $\mathrm{Se}(\mathrm{IV})-\mathrm{AFm}$ & -28.4 & -7152 & -8056 & 727.2 & 877.6 & 337 \\
\hline $3 \mathrm{CaO} \cdot \mathrm{Al}_{2} \mathrm{O}_{3} \cdot \mathrm{CaSeO}_{3} \cdot 11 \mathrm{H}_{2} \mathrm{O}$ & \pm 0.8 & & & & & \\
\hline
\end{tabular}




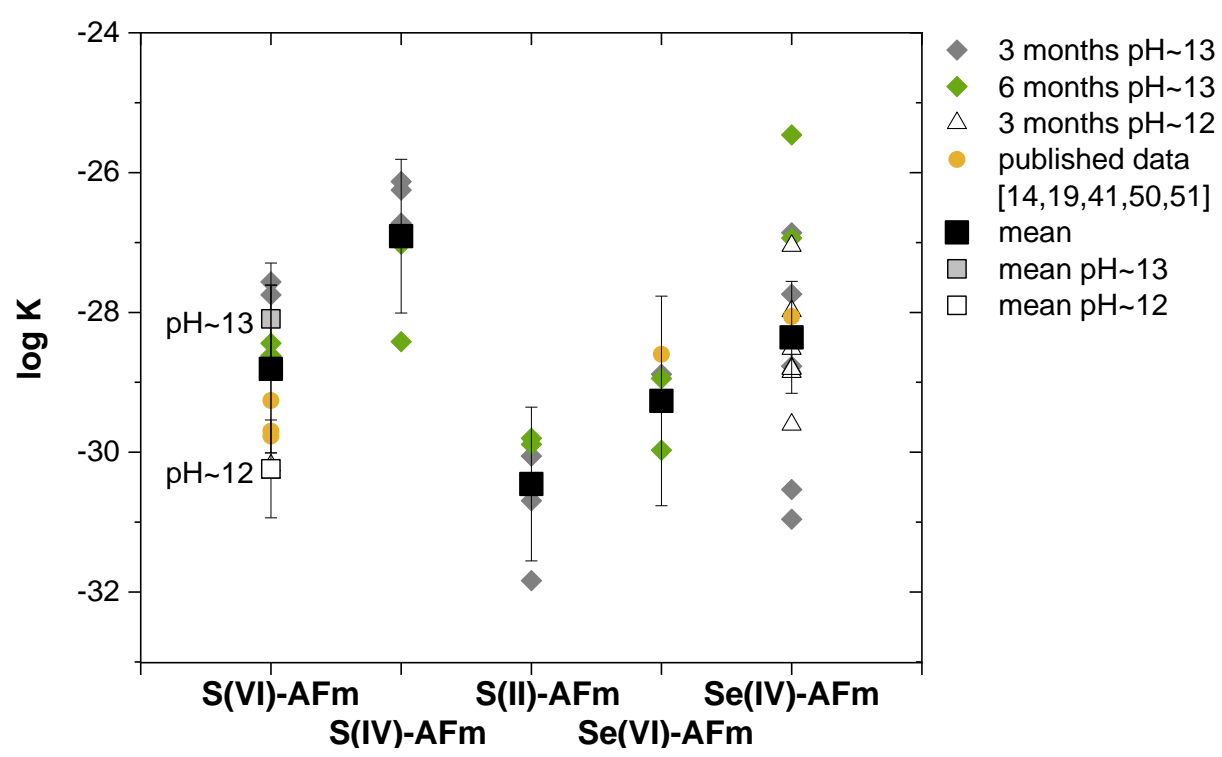

Figure 11: Solubility products of the synthesized AFm phases determined at $20^{\circ} \mathrm{C}$ and different equilibration time and $\mathrm{pH}$. Calculated error on the mean values indicate the $95 \%$ confidence interval. Black squares represent the mean values of all measurements; for the $\mathrm{S}(\mathrm{VI})-\mathrm{AFm}$ additionally mean values for $\mathrm{pH} 13$ (light grey square) and $\mathrm{pH} 12$ (white square) are shown.

\section{Conclusions}

The present study shows that the sulfur and selenium species S(VI), S(IV), S(II), Se(VI) and Se(IV) can be incorporated in the AFm-type phases. Such phases display the lamellar structure typical for the AFm family with trigonal or pseudo-trigonal symmetry (lowering of the symmetry observed) depending on the type of the interlayer anion and its coordination. The phases described in the hexagonal lattice are characterized by identical position of the (110) main layer reflection but different interlayer distances (00I harmonics). The latter distances depend on the size of the anion and/or the number of water molecules present in the interlayer. The attempt to refine the structure of these AFm phases was partially conclusive while it is acknowledged that more detailed investigations are needed. 
The total amount of water was estimated by TGA. The number of $\mathrm{H}_{2} \mathrm{O}$ molecules in the structure was determined to be $11 \mathrm{H}_{2} \mathrm{O}$ for the S(IV)- and Se(IV)-AFm, $12 \mathrm{H}_{2} \mathrm{O}$ for the $\mathrm{S}(\mathrm{VI})-\mathrm{AFm}$, and $13 \mathrm{H}_{2} \mathrm{O}$ for the $\mathrm{Se}(\mathrm{VI})-$ and the S(II)-AFm. The different types of structurally bound water can readily be identified by FTIR and Raman based on the position of the absorption peaks. The S(VI)-, S(II)- and Se(VI)-AFm can exist in several hydration states depending on the relative humidity of exposure.

All AFm show similar solubility products with the S(IV)-AFm being the least stable. The Se(IV)-AFm shows the largest scatter presumably as a result of its poor crystallinity. These similar solubilities suggest that high sulfur concentration in the pore solution of the cement can decrease the extent of $\mathrm{Se}$ binding by AFm phases.

\section{Acknowledgements}

The research leading to these results has received funding from the European Union's Horizon 2020

Research and Training Programme of the European Atomic Energy Community (EURATOM) (H2020NFRP-2014/2015) under grant agreement $n^{\circ} 662147$ (CEBAMA). The authors would like to thank Luigi Brunetti (Empa), Dr. Frank Winnefeld (Empa) and Dr. Mateusz Wyrzykowski (Empa) for their support in the sample characterization measurements. Dr. Erich Wieland (PSI) is greatly acknowledged for the helpful discussions and for revising the manuscript.

\section{References}

[1] A. Gruskovnjak, B. Lothenbach, F. Winnefeld, R. Figi, S.-C. Ko, M. Adler, U. Mäder, Hydration mechanisms of super sulphated slag cement, Cem. Concr. Res. 38 (2008), 983-992. https://doi.org/10.1016/j.cemconres.2008.03.004. 
[2] B. Lothenbach, G. Le Saout, M. Ben Haha, R. Figi, E. Wieland, Hydration of low-alkali CEM III/B-

$\mathrm{SiO}_{2}$

cement

(LAC),

Cem. Concr.

Res.

42

(2012),

410-423.

712 https://doi.org/10.1016/j.cemconres.2011.11.008.

713 [3] T. Matschei, B. Lothenbach, F.P. Glasser, The AFm phase in Portland cement, Cem. Concr. Res.

37 (2007), 118-130. https://doi.org/10.1016/j.cemconres.2006.10.010.

715 [4] NAGRA Project Opalinus Clay. Safety report. Demonstration of disposal feasibility for spent fuel, vitrified high-level waste and long-lived intermediate level waste, Nagra Technical Report NTB 0205 (2002), Nagra, Wettingen, Switzerland.

[5] P. Wersin, L.H. Johnson, B. Schwyn, U. Berner, E. Curti, Redox conditions in the near field of a repository for SF/HLW and ILW in Opalinus clay, Nagra Technical Report NTB 02-13 (2003), Nagra, Wettingen, Switzerland.

[6] Å. Olin, B. Noläng, E.G. Osadchii, L.-O. Öhman, E. Rosén, Chemical thermodynamics of Selenium, Elsevier, Amsterdam, 2005.

[7] H. Fischer, G. Schulz-Ekloff, D. Wöhrle, Oxidation of aqueous sulfide solutions by dioxygen. Part

I: Autoxidation reaction, Chem. Eng.Technol. 20 (1997), 462-468.

[8] H. F. W. Taylor, Cement Chemistry; second ed., Thomas Telford, London, 1997.

[9] D. G. Evans \& R. C. T. Slade, Structural aspects of layered double hydroxides, in: X. Duan, D. G.

[10] G. Renaudin \& M. François, The lamellar double-hydroxide (LDH) compound with composition

https://doi.org/10.1107/S0108270199003066.

[11] L. Aimoz, E. Wieland, C. Taviot-Guého, R. Dähn, M. Vespa, S.V. Churakov, Structural insight into 
[12] G. Renaudin, J.P. Rapin, E. Elkaim, M. François, Polytypes and polymorphs in the related Friedel's salt $\left[\mathrm{Ca}_{2} \mathrm{Al}(\mathrm{OH})_{6}\right]^{+}\left[\mathrm{X} \cdot 2 \mathrm{H}_{2} \mathrm{O}\right]^{-}$halide series, Cem. Concr. Res. 34 (2004), 1845-1852. https://doi.org/10.1016/j.cemconres.2004.01.003.

[13] R. Segni, N. Allali, L. Vieille, C. Taviot-Guého, F. Leroux, Hydrocalumite-type materials: 2. Local order into $\mathrm{Ca}_{2} \mathrm{Fe}(\mathrm{OH})_{6}\left(\mathrm{CrO}_{4}{ }^{2-}\right)_{0.5} \cdot \mathrm{nH}_{2} \mathrm{O}$ in temperature studied by X-ray absorption and Mössbauer spectroscopies, J. Phys. Chem. Solids 67 (2006), 1043-1047. https://doi.org/10.1016/j.jpcs.2006.01.023.

[14] S.M. Leisinger, B. Lothenbach, G. Le Saout, C.A. Johnson, Thermodynamic modeling of solid solutions between monosulfate and monochromate $3 \mathrm{CaO} \cdot \mathrm{Al}_{2} \mathrm{O}_{3} \cdot \mathrm{Ca}\left[\left(\mathrm{CrO}_{4}\right)_{\mathrm{x}}\left(\mathrm{SO}_{4}\right)_{1-\mathrm{x}}\right] \cdot \mathrm{nH} \mathrm{H}_{2} \mathrm{O}, \mathrm{Cem}$. Concr. Res. 42 (2012), 158-165. https://doi.org/10.1016/j.cemconres.2011.09.005.

[15] B. Ma, A. Fernandez-Martinez, S. Grangeon, C. Tournassat, N. Findling, F. Claret, A. Koishi, N.C.M. Marty, D. Tisserand, S. Bureau, E. Salas-Colera, E. Elkaïm, C. Marini, L. Charlet, Evidence of multiple sorption modes in layered double hydroxides using Mo as structural probe, Environ. Sci. Technol. 51 (2017), 5531-5540. https://doi.org/10.1021/acs.est.7b00946.

[16] A. Mesbah, C. Cau-dit-Coumes, F. Frizon, F. Leroux, J. Ravaux, G. Renaudin, A new investigation of the $\mathrm{Cl}^{-}-\mathrm{CO}_{3}{ }^{2-}$ substitution in AFm phases, J. Am. Ceram. Soc. 94 [6] (2011), 1901-1910. https://doi.org/10.1111/j.1551-2916.2010.04305.x.

[17] A. Mesbah, M. François, C. Cau-dit-Coumes, F. Frizon, Y. Filinchuk, F. Leroux, J. Ravaux, G. Renaudin, Crystal structure of Kuzel's salt $3 \mathrm{CaO} \cdot \mathrm{Al}_{2} \mathrm{O}_{3} \cdot 1 / 2 \mathrm{CaSO}_{4} \cdot 1 / 2 \mathrm{CaCl}_{2} \cdot 11 \mathrm{H}_{2} \mathrm{O}$ determined by synchrotron powder diffraction, Cem. Concr. Res. $41 \quad$ (2011), 504-509. https://doi.org/10.1016/j.cemconres.2011.01.015.

[18] A. Mesbah, J.P. Rapin, M. François, C. Cau-dit-Coumes, F. Frizon, F. Leroux, G. Renaudin, Crystal structures and phase transition of cementitious bi-anionic $\mathrm{AFm}-\left(\mathrm{Cl}^{-}, \mathrm{CO}_{3}{ }^{2-}\right)$ compounds, J. Am. Ceram. Soc. 94 [1] (2011), 261-268. https://doi.org/10.1111/j.1551-2916.2010.04050.x.

[19] L. Aimoz, D.A. Kulik, E. Wieland, E. Curti, B. Lothenbach, U. Mäder, Thermodynamics of AFm$\left(\mathrm{I}_{2}, \mathrm{SO}_{4}\right)$ solid solution and of its end-members in aqueous media, Appl. Geochem. 27 (2012), 21172129. https://doi.org/10.1016/j.apgeochem.2012.06.006. 
carboaluminate and carbonated calcium hemicarboaluminate from synchrotron powder diffraction da-

ta, Acta Cryst. B68 (2012), 493-500. https://doi.org/10.1107/S010876811203042X.

[21] I. Baur \& C.A. Johnson, Sorption of selenite and selenate to cement minerals, Environ. Sci.

764

765

766

767

768

769

770

771

772

773

774

775

776

777

778

779

780

781 Technol. 37 (2003), 3442-3447. https://doi.org/10.1021/es020148d.

[22] I. Bonhoure, I. Baur, E. Wieland, C.A. Johnson, A.M. Scheidegger, Uptake of Se(IV/VI) oxyanions by hardened cement paste and cement minerals: An X-ray absorption spectroscopy study, Cem. Concr. Res. 36 (2006), 91-98. https://doi.org/10.1016/j.cemconres.2005.05.003.

[23] M. Zhang, Incorporation of oxyanionic $\mathrm{B}, \mathrm{Cr}, \mathrm{Mo}$, and Se into hydrocalumite and ettringite: Application to cementitious systems, PhD Thesis at the University of Waterloo, Ontario, Canada, 2000.

[24] H. Rojo, A.C. Scheinost, B. Lothenbach, A. Laube, E. Wieland, J. Tits, Retention of selenium by calcium aluminate hydrate (AFm) phases under strongly-reducing radioactive waste repository conditions, Dalton Transactions 00 (2018), 1-10. https://doi.org/10.1039/c7dt04824f.

[25] R. Allmann, Refinement of the hybrid layer structure $\left[\mathrm{Ca}_{2} \mathrm{Al}(\mathrm{OH})_{6}\right]^{+} \cdot\left[\frac{1}{2} \mathrm{SO}_{4} \cdot 3 \mathrm{H}_{2} \mathrm{O}\right]^{-}$, Neues Jb Miner. Monat. 3 (1977), 136-144.

[26] L.G. Baquerizo, T. Matschei, K.L. Scrivener, M. Saeidpour, A. Thorell, L. Wadsö, Methods to determine hydration states of minerals and cement hydrates, Cem. Concr. Res. 65 (2014), 85-95. https://doi.org/10.1016/j.cemconres.2014.07.009.

[27] L.G. Baquerizo, T. Matschei, K.L. Scrivener, M. Saeidpour, L. Wadsö, Hydration states of AFm cement phases, Cem. Concr. Res. 73 (2015), 143-157. https://doi.org/10.1016/j.cemconres.2015.02.011. [28] H. Motzet \& H. Pöllmann, Synthesis and characterization of sulfite-containing AFm phases in the system $\mathrm{CaO}-\mathrm{Al}_{2} \mathrm{O}_{3}-\mathrm{SO}_{2}-\mathrm{H}_{2} \mathrm{O}$, Cem. Concr. Res. 29 (1999), 1005-1011. https://doi.org/10.1016/S0008-8846(99)00082-4.

[29] D. Le Cornec, Q. Wang, L. Galoisy, G. Renaudin, L. Izoret, G. Calas, Greening effect in slag cement materials, Cem. Concr. Res. 84 (2017), 93-98. https://doi.org/10.1016/j.cemconcomp.2017.08.017. 
[30] C. Vernet, Comportement de l'ion S-- au cours de l'hydratation des ciments riches en laitier (CLK). Formation de solutions solides de S-- dans les aluminates hydrates hexagonaux, Silicates Industriels 3 (1982), 85-90.

[31] I. Puigdomenech, INPUT, SED, and PREDOM: Computer programs drawing equilibrium diagrams; TRITA-OOK-3010, Royal Institute of Technology (KTH), Dept. Inorg. Chemistry, Stockholm, Sweden, 1983.

[32] H. Wanner, The NEA thermochemical data base project, Radiochim. Acta 44/45 (1988), 325-329. https://doi.org/10.1524/ract.1988.4445.2.325.

[33] M.A. Neumann, X-Cell: a novel indexing algorithm for routine tasks and difficult cases, J. Appl. Cryst. 36 (2003), 356-365.

[34] V. Favre-Nicolin \& R. Černý, FOX, free objects for crystallography: a modular approach to ab initio structure determination from powder diffraction, J. Appl. Cryst. 35 (2002), 734-743. https://doi.org/10.1107/S0021889802015236.

[35] J. Rodriguez-Carvajal, PROGRAM FullProf, 2k-version 3.20, Laboratoire Léon Brillouin (CEACNRS), France, 2005.

[36] D.A. Kulik, T. Wagner, S.V. Dmytrieva, G. Kosakowski, F.F. Hingerl, K.V. Chudnenko, U. Berner GEM-Selektor geochemical modeling package: revised algorithm and GEMS3K numerical kernel for coupled simulation codes, Computational Geosciences 17 (2013), 1-24. https://doi.org/10.1007/s10596-012-9310-6.

[37] W. Hummel, U. Berner, E. Curti, F. J. Pearson, T. Thoenen, Nagra/PSI thermodynamic database 01/01, Universal Publisher/uPublish.com, Parkland, Florida, 2002.

[38] Y. Gu, C.H. Gammons, M.S. Bloom, A one-term extrapolation for estimating equilibrium constants of aqueous reactions at elevated temperatures, Geochem. Cosmochim. Acta 58 (1994), 35453560. https://doi.org/10.1016/0016-7037(94)90149-X. 

https://doi.org/10.1038/2181048a0.

811 [40] J.B. Champenois, A. Mesbah, C.C.D. Coumes, G. Renaudin, F. Leroux, C. Mercier, B. Revel, D. 812 Damidot, Crystal structures of Boro-AFm and sBoro-AFt phases, Cem. Concr. Res. 42 (2012), $1362-$ 813 1370. https://doi.org/10.1016/j.cemconres.2012.06.003.

814 [41] B. Ma, A. Fernandez-Martinez, S. Grangeon, C. Tournassat, N. Findling, S. Carrero, D. Tisserand, S. Bureau, E. Elkaïm, C. Marini, G. Aquilanti, A. Koishi, N. Marty, L. Charlet, Selenite uptake by CaAl LDH: A description of intercalated anion coordination geometries, Environ. Sci. Technol. 52 (2018), 16241632. https://doi.org/10.1021/acs.est.7b04644.

[42] M. Wildner \& G. Giester, Crystal structures of $\mathrm{SrSeO}_{3}$ and $\mathrm{CaSeO}_{3}$ and their respective relationships with molybdomenite- and monazite-type compounds - an example for stereochemical equivalence of $\mathrm{ESeO}_{3}$ groups $\left(\mathrm{E}=\right.$ lone electron pair) with tetrahedral $\mathrm{TO}_{4}$ groups, N. Jb Min., Abh. 184/1 (2007), 29-37. https://doi.org/10.1127/0077-7757/2007/0083. tallogr. 181 (1987), 29-34. https://doi.org/10.1524/zkri.1987.181.14.29.

[44] M. Francois, G. Renaudin, O. Evrard, A cementitious compound with composition https://doi.org/10.1107/S0108270198004223.

[45] H. Pöllmann, Die Kristallchemie der Neubildung bei Einwirkung von Schadstoffen auf hydraulische Bindelmittel, PhD Thesis at the University of Erlangen, Germany, 1984. John Wiley \& Sons, New Jersey, 1986.

[47] H. Siebert, Kraftkonstante und Strukturchemie. V. Struktur der Sauerstoffsäuren , Z. anorg. allg. Chemie 275 (1954), 225-240. https://doi.org/10.1002/zaac.19542750407. 
835 [49] G. Renaudin, R. Segni, D. Mentel, J.M. Nedelec, F. Leroux, C. Taviot-Gueho, A Raman study of 836 the sulfated cement hydrates: ettringite and monosulfoaluminate, J. Adv. Concr. Techn. 5A (2007), 299837 312. https://doi.org/10.3151/jact.5.299.

838 [50] T. Matschei, B. Lothenbach, F.P. Glasser, Thermodynamic properties of Portland cement hy839 drates in the system $\mathrm{CaO}-\mathrm{Al}_{2} \mathrm{O}_{3}-\mathrm{SiO}_{2}-\mathrm{CaSO}_{4}-\mathrm{CaCO}_{3}-\mathrm{H}_{2} \mathrm{O}$, Cem. Concr. Res. 37 (2007), 1379-1410. 840 https://doi.org/10.1016/j.cemconres.2007.06.002.

841 [51] I. Baur \& C.A. Johnson, The solubility of selenate-AFt $\left(3 \mathrm{CaO} \cdot \mathrm{Al}_{2} \mathrm{O}_{3} \cdot 3 \mathrm{CaSeO}_{3} \cdot 37 \cdot 5 \mathrm{H}_{2} \mathrm{O}\right)$ and sele842 nate-AFm $\left(3 \mathrm{CaO} \cdot \mathrm{Al}_{2} \mathrm{O}_{3} \cdot \mathrm{CaSeO}_{4} \cdot \mathrm{xH}_{2} \mathrm{O}\right)$, Cem. Concr. Res. 33 (2003), 1741-1748. 843 https://doi.org/10.1016/S0008-8846(03)00151-0.

844

845

846

\section{Appendix}

847 A.1: Measured IC concentrations, $\mathrm{pH}$ and solubility products for the S-AFm phases at $20^{\circ} \mathrm{C}$.

848

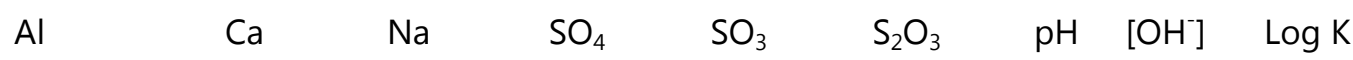

849 $[\mathrm{mmol} / \mathrm{l}]$ $[\mathrm{mmol} / \mathrm{l}][\mathrm{mmol} / \mathrm{l}] \quad[\mathrm{mr}$ mmol/l] $[\mathrm{mm}$ $[\mathrm{mmol} / \mathrm{l}] \quad[\mathrm{mmol} / \mathrm{l}] \quad[\mathrm{mmol}]$

850

851 sulfate: $S(V I)$

8523 months; $\mathrm{pH} 13$

$853 \quad \# 1 \quad 7.21 \quad 0.642 \quad 206.5 \quad 1.22$

$\begin{array}{llllll}854 & \# 2 & 13.74 & 0.551 & 229.6 & 3.67\end{array}$

$13.2 \quad 0.161 \quad-27.75$

8556 months; $\mathrm{pH} 13$

$\begin{array}{llllllllll}856 & \# 1 & 4.47 & 0.646 & 216.2 & 1.35 & 13.1 & 0.137 & -28.62 \\ 857 & \# 2 & 2.64 & 0.902 & 211.0 & 1.50 & 13.1 & 0.125 & -28.44\end{array}$

8583 months; $\mathrm{pH} 12$

859

$\begin{array}{llll}\# 1 & 1.41 & 6.28 & 0.565\end{array}$

$\begin{array}{lll}12.1 & 0.012 & -30.19\end{array}$

860

\#2 $\quad 0.551$

$5.73 \quad 0.548<.052$

$12.2 \quad 0.016 \quad-30.29$ 
862 sulfite: S(IV)

8633 months; $p H \sim 13$

$864 \quad$ \#1 14.46

$0.616 \quad 207.1$

6.40 *

$\begin{array}{lll}13.2 & 0.132 & -26.72\end{array}$

$865 \quad$ \#2 16.13

$0.664 \quad 205.9$

$7.92 *$

$\begin{array}{lll}13.3 & 0.189 & -26.13\end{array}$

$866 \quad$ \#3 15.56

$0.640 \quad 206.6$

$8.02 *$

$\begin{array}{lll}13.3 & 0.174 & -26.25\end{array}$

$867 \quad 6$ months; $p H \sim 13$

$0.623 \quad 224.3$

$7.13^{*}$

$\begin{array}{lll}13.1 & 0.122 & -27.02\end{array}$

$869 \quad$ \#2 2.38

$0.732 \quad 211.6$

$4.41^{*}$

$\begin{array}{lll}13.1 & 0.116 & -28.42\end{array}$

870

871 thiosulfate: S(II)

8723 months; $p H \sim 13$

$\begin{array}{lllll}873 & \# 1 & 0.056 & 3.29 & 172.5\end{array}$

$\begin{array}{llll}<.045 & 13.2 & 0.141 & -30.62\end{array}$

$874 \quad \# 2 \quad 0.395$

$1.66 \quad 162.4$

$\begin{array}{llll}0.100 & 13.0 & 0.107 & -30.05\end{array}$

$875 \quad \# 3 \quad 0.066$

$2.48 \quad 179.4$

$\begin{array}{llll}0.016 & 13.1 & 0.117 & -31.84\end{array}$

8766 months; $p H \sim 13$

$877 \quad \# 1 \quad 0.268$

$3.15 \quad 176.0$

$\begin{array}{llll}0.026 & 13.1 & 0.112 & -29.89\end{array}$

$878 \quad$ \#2 0.296

$3.18 \quad 172.7$

$\begin{array}{llll}0.028 & 13.0 & 0.107 & -29.80\end{array}$

879 * values corrected for sulfite oxidation.

880

881

882 A.2: Measured IC concentrations, $\mathrm{pH}$ and solubility products for the Se-AFm phases at $20^{\circ} \mathrm{C}$.

883

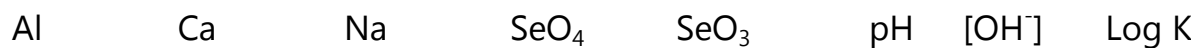

884 $[\mathrm{mmol} / \mathrm{l}] \quad[\mathrm{mmol} / \mathrm{l}] \quad[\mathrm{mmol} / \mathrm{l}] \quad[\mathrm{mmol} / \mathrm{l}] \quad[\mathrm{mmol} / \mathrm{l}]$ [mmol]

885

886 selenate: $\mathrm{Se}(\mathrm{VI})$ 
8873 months; $p H \sim 13$

$888 \quad \# 1$

$\begin{array}{llll}0.242 & 3.02 & 169.0 & 0.169\end{array}$

$\begin{array}{lll}13.2 & 0.137 & -28.88\end{array}$

8896 months; $p H \sim 13$

$\begin{array}{lllllllll}890 & \# 1 & 0.220 & 1.88 & 189.6 & 0.291 & 13.1 & 0.122 & -29.97 \\ 891 & \# 2 & 0.266 & 2.98 & 188.2 & 0.339 & 13.1 & 0.112 & -28.94\end{array}$

892

893 selenite: $\mathrm{Se}(I V)$

8943 months; $p H \sim 13$

$895 \quad \# 1$

$20.24 \quad 0.842 \quad 225.6$

0.498

$\begin{array}{lll}13.2 & 0.155 & -26.86\end{array}$

$896 \quad \# 2$

$\begin{array}{lll}7.81 & 0.526 & 154.8\end{array}$

0.257

$\begin{array}{lll}13.0 & 0.091 & -28.48\end{array}$

$897 \quad \# 3$

$\begin{array}{lll}5.25 & 0.619 & 156.7\end{array}$

0.161

$\begin{array}{lll}13.0 & 0.103 & -27.74\end{array}$

$898 \quad \# 4$

$\begin{array}{lll}5.08 & 0.181 & 152.4\end{array}$

0.253

$\begin{array}{lll}13.0 & 0.099 & -30.96\end{array}$

$899 \quad \# 5$

$\begin{array}{lll}15.92 & 0.657 & 205.7\end{array}$

0.590

$\begin{array}{lll}13.2 & 0.154 & -28.77\end{array}$

$900 \quad \# 6$

14.36

$0.289 \quad 154.9$

0.221

$\begin{array}{lll}13.0 & 0.099 & -30.53\end{array}$

9016 months; $p H \sim 13$

$902 \quad \# 1$

16.63

0.300

228.5

$903 \quad \# 2$

$\begin{array}{lll}19.99 & 0.880 \quad 240.0\end{array}$

9043 months; $p H \sim 12$

$905 \quad \# 1$

$\begin{array}{lll}2.59 & 7.50 & 0.423\end{array}$

$906 \quad$ \#2

$\begin{array}{lll}3.72 & 6.67 & 0.420\end{array}$

$907 \quad \# 3$

$\begin{array}{lll}0.103 & 7.34 & 1.73\end{array}$

$908 \quad \# 4$

$\begin{array}{lll}3.12 & 6.99 & 1.71\end{array}$

$909 \quad \# 5$

2.65

$910 \quad \# 6$

$\begin{array}{lll}0.125 & 7.44 & 1.76\end{array}$

$2.58 \quad 7.91$

0.394

\begin{tabular}{ll}
$7.91-0.394$ \\
\hline
\end{tabular}

0.676

1.01

$\begin{array}{lll}13.1 & 0.127 & -25.46\end{array}$

$\begin{array}{lll}13.1 & 0.121 & -26.94\end{array}$

911 \#7
0.080

0.012

0.305

0.004

0.001

0.139

0.013 $\begin{array}{lll}12.3 & 0.017 & -27.05\end{array}$

$\begin{array}{lll}12.0 & 0.009 & -28.52\end{array}$

$\begin{array}{lll}12.4 & 0.027 & -28.85\end{array}$

$\begin{array}{lll}12.1 & 0.012 & -28.80\end{array}$

$\begin{array}{lll}12.3 & 0.021 & -28.81\end{array}$

$\begin{array}{lll}12.2 & 0.015 & -29.60\end{array}$

$\begin{array}{lll}12.2 & 0.015 & -27.98\end{array}$ 